\title{
Color for Life: Biosynthesis and Distribution of Phenolic Compounds in Pepper (Capsicum annuum)
}

\author{
Virgínia Carvalho Lemos ${ }^{1,2}$, Julia Jessica Reimer ${ }^{1,2}$ and Alexandra Wormit ${ }^{1,2, *(1)}$ \\ 1 Institute of Biology 1, Botany and Molecular Genetics, RWTH Aachen University, Worringerweg 3, \\ 52074 Aachen, Germany; lemos@bio1.rwth-aachen.de (V.C.L.); reimer@bio1.rwth-aachen.d (J.J.R.) \\ 2 Bioeconomy Science Center (BioSC), Forschungszentrum Jülich, Wilhelm Johnen Straße, \\ 52425 Jülich, Germany \\ * Correspondence: awormit@bio1.rwth-aachen.de; Tel.: +49-241-80-26766
}

Received: 31 March 2019; Accepted: 16 April 2019; Published: 19 April 2019

\begin{abstract}
Fruits and vegetables are an important supplier of biological active substances, such as vitamins and secondary metabolites (SM) for human nutrition, but also for further industrial applications. Pepper (Capsicum annuum) is grown and consumed all over the world as a fresh vegetable or dried as a spice. It is also used as a coloring agent, as well for medical purposes. Pepper fruits are considered as an attractive source of health-related compounds, but other organs like the leaves and stem also contain considerable amounts of antioxidants, e.g., phenolic compounds. This indicates potential for valorization of residual biomass from horticultural production by using innovative bioeconomic concepts. Herein, we present an overview about the biosynthesis of phenolic compounds, with a special focus on flavonoids and their regulation in pepper, the current knowledge of amounts and distribution of these valuable substances, as well as possible strategies for: (1) increasing flavonoid contents in pepper, (2) improving the nutritional value of fruits, and (3) new concepts for utilization of residual biomass from horticultural production.
\end{abstract}

Keywords: secondary metabolites; phenolic compounds; biosynthesis; flavonoids; human nutrition; industrial application; Capsicum annuum; pepper

\section{Secondary Metabolites from Fruits and Vegetables are of High Value for Human Nutrition and Industrial Applications}

Fruits and vegetables are an important source of phytochemicals and secondary metabolites (SM). The health-promoting properties of fruits and vegetables have long been recognized and, as a result, recommendations for daily consumption have been issued by e.g., the World Health Organization (WHO) [1] and many different countries [2,3].

Plants produce more than 200,000 different SM [4], which have no direct function in growth and maintenance of cells, but can be bio-active, and have a major role in the adaptation of plants to their environment such as protection against different forms of stresses $[5,6]$. For example, SM have a key role in protecting plants from herbivores and pathogens [7-10], and they can serve as UV protectants [11,12], or signaling molecules to attract pollinators [13-15].

Plant SM play an important role for human nutrition as they are significant determinants of the quality of fruits and vegetables. Some major groups of SM can be distinguished: Phenylpropanoids or phenolic compounds, terpenoids, alkaloids, and sulfuric compounds [16]. Phenolic compounds derived from plant tissues, especially flavonoids, have been shown to possess beneficial properties for human health and disease prevention $[17,18]$, including antioxidant, antibacterial, and antiviral properties [19,20]. Protective effects have been observed for the flavonoids kaempferol, naringenin, and apigenin [21-24], and for other phenolic compounds against chronic diseases such as cardiovascular 
disease, Type II diabetes, and certain cancers [25-29]. SM are also of high value for industrial applications as they represent an important source of new pharmaceutics or phytomedicines, antibiotics, cosmetics, flavors, fragrances, pesticides or fine chemicals. Plant SM are used in their natural or derivatized form or might serve as backbones for the synthesis of several valuable metabolites [30,31], e.g., approximately $60 \%$ of anticancer compounds and $75 \%$ of drugs for infectious diseases are derived from these natural products.

Peppers (Capsicum) are considered to have a high nutritional value due to their content of phytochemicals with known antioxidant capacity [32]. The genus Capsicum, comprising (non-pungent) bell peppers and chilies, belongs to the Solanaceae family and contains five domesticated species: Capsicum annuum L., Capsicum chinense Jacq., Capsicum frutescens L., Capsicum baccatum L., and Capsicum pubescens Ruiz \& Pav. The most varieties are found among the group of Capsicum annuum, which is also the economically most important species [33]. Peppers are consumed as a fresh or cooked vegetable or dried as a spice. Further, the industry uses peppers intensively as a spice or coloring agent in many foodstuffs. Peppers are grown worldwide, primarily in tropical and subtropical countries, but are also cultivated in temperate climates in greenhouses [34]. The production of peppers has been constantly increasing over the last 20 years, both in terms of cultivation area and fruit production (Figure 1A).

A

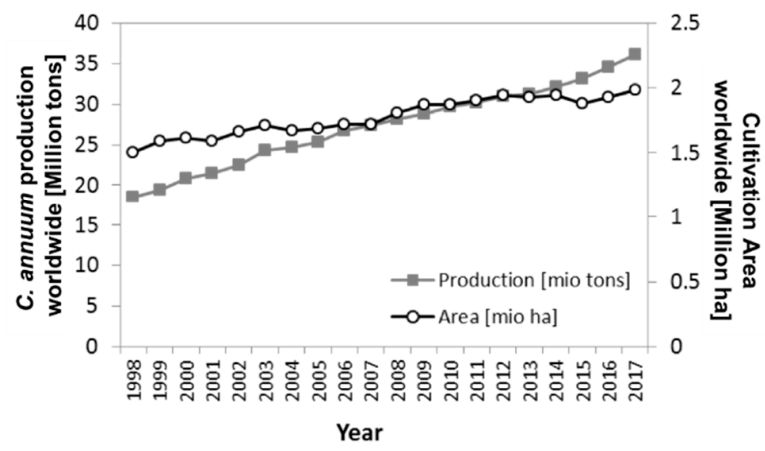

B

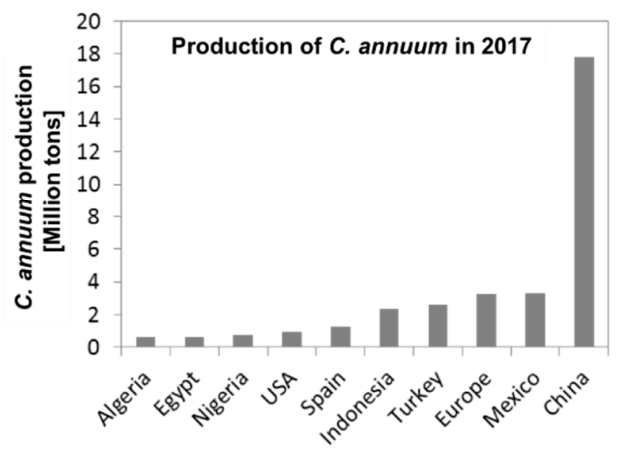

Figure 1. Capsicum annuum production statistics [35]. (A) Pepper production (grey line and squares, in million tons) and Cultivation Area (black line with white circles, in million ha) worldwide from 1998 until 2017. (B) Production (in million tons) of pepper in the 10 most producing countries in 2017.

In 2017, the world production of fresh peppers reached over 35 million tons of fruits harvested on almost two million ha land [35]. China was the largest producer in 2017 with more than 17 million tons of peppers, followed by Mexico, Europe, Turkey and Indonesia, who produced between one and 3.3 million tons that year (Figure 1B) [35]. Pepper fruits are an excellent source of bio-active compounds, such as vitamins, carotenoids and phenolics and have been reported to have one of the highest antioxidant capacities among vegetables [36-38]. Their suitability to tackle human micronutrient deficiency has been discussed previously $[39,40]$.

The aim of this review is to give first an overview about the different classes of phenolic compounds and their biosynthesis, with a special focus on flavonoids. Further, the current knowledge about the phenolic composition of Capsicum annuum will be comprehensively reviewed and lastly, potential approaches for production of beneficial phenolic compounds in pepper, for health benefits and industrial utilization, will be discussed.

\section{Phenolic Compounds-Structure and Biosynthesis}

\subsection{Definition and Structure of Phenolic Compounds}

Phenylpropanoids and phenolic compounds originate from plant secondary metabolism. Both derive from the shikimate pathway with phenylalanine or tyrosine as intermediates [41]. They are 
based on the structure of the family's central element, respectively, the aromatic or phenolic ring, often in combination with a propyl group (as it is the fact for phenylpropanoids) [42].

Based on the existing number of phenol units, phenolic compounds can either be classified as simple phenols (only one phenol unit) or polyphenols. Polyphenols consist of two or more phenolic groups, up to polymeric structures (the later will not be discussed further in this review). They have often one hydroxyl group attached to the molecule's various benzene rings [42]. In addition, polyphenols appear rarely as free compounds, but can be found in the form of esters or glycosides in plants [42,43]. They possess antioxidant properties, and their activity depends on the number and position of the hydroxyl groups and on the surrounding $\mathrm{pH}$ [44]. Phenolic compounds are further divided in different classes according to their chemical structure and number of carbons [42]. For example, phenolic acids have a $\mathrm{C} 6-\mathrm{C} 1$ basic skeleton while flavonoids have a $\mathrm{C} 6-\mathrm{C} 3-\mathrm{C} 6$ structure.

The polyphenolic nature of flavonoids enables them to scavenge free radicals such as superoxide and hydroxyl radicals [45]. Their C6-C3-C6 skeleton is composed of two benzene rings (ring A and B) that are linked together by three carbons (see Figure 2). It was established that ring $\mathrm{A}$ is located on the left side and results from the condensation of three malonyl-CoA molecules; ring B results from p-coumaroyl-CoA (from the shikimate pathway) and is located on the right side [42]. Flavonoids can be further subdivided in at least eight subgroups depending on substitutions and formation of an additional O-heterocycle (adapted from [46,47]). Many of the subgroups contain an O-heterocycle with six atoms, and only aurones have the O-heterocycle build of five atoms, while chalcones do not show any heterocyclization. In each class of flavonoids, the substitutions in the rings $\mathrm{A}$ and $\mathrm{B}$ give origin to different compounds. These substitutions may be derived from oxygenation, alkylation, glycosylation, acylation, isoprenylation and sulfonation reactions [42].

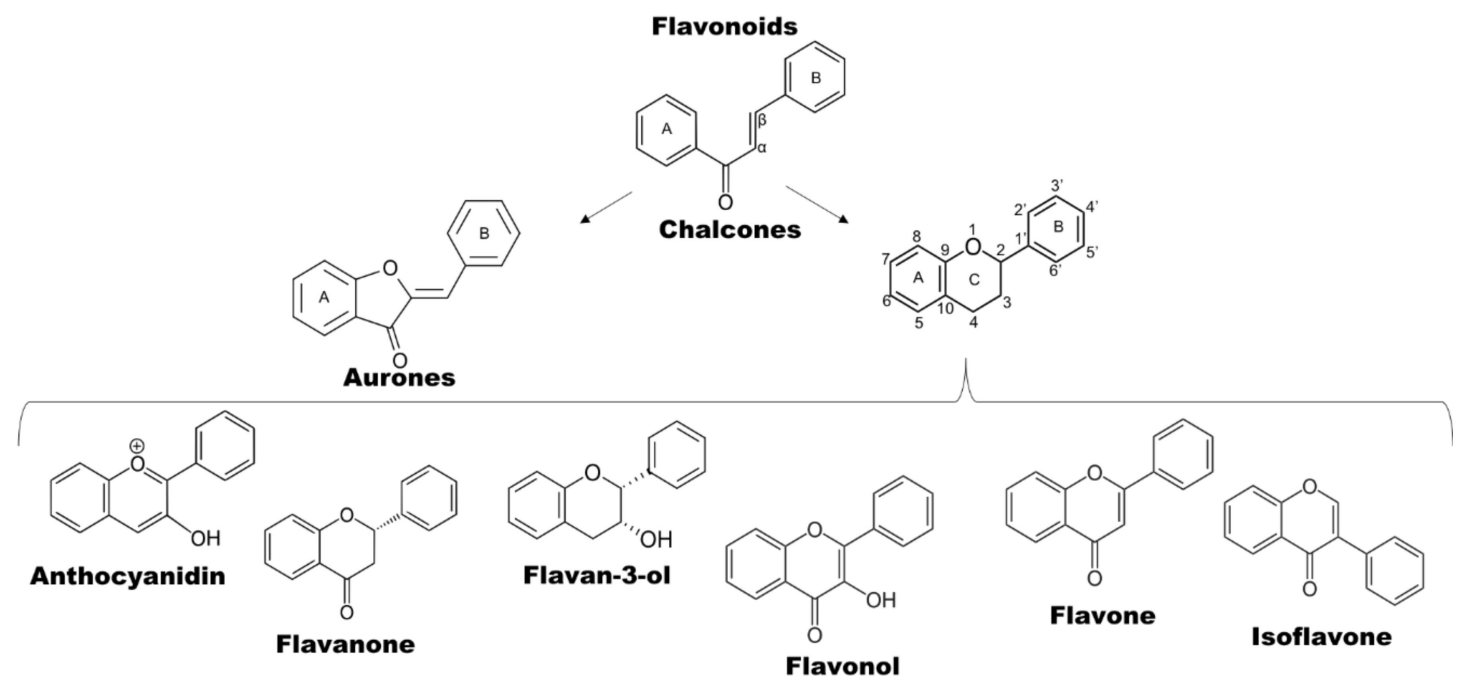

Figure 2. Subclasses of flavonoids. The central structure of flavonoids is shown for flavan, and for each subgroup the corresponding structure is shown as described in the text. Adapted from $[42,46]$.

Chalcones are aromatic ketones based on the structure of 1-phenylethanone, in which one of the methyl hydrogens is substituted by a benzylidene group. Therefore, chalcones have two benzene rings, ring $\mathrm{A}$ and ring $\mathrm{B}$, connected by a bridge harboring a keton conjugated to an $\alpha, \beta$-unsaturated carbonyl (enone). In the case of dihydrochalcones, the carbon chain is saturated (no double bond). In all other subgroups this carbon bridge is part of a heterocycle. Aurones result from the cyclization of chalcones when a meta-hydroxyl group reacts with the $\alpha$-carbon of the double bond to form a heterocycle with five atoms between ring A and B [42]. In typical flavonoids, a meta-hydroxy group of the ring A contributes with an atom of oxygen to the formation of a six atom-heterocycle (sometimes referred to as ring $C$ ) reacting with the $\beta$-carbon [42]. Besides chalcones and aurones, the classification of the further six subclasses depends on the substitution pattern of the aliphatic central ring C (Figure 2), 
resulting in flavones, flavonols, flavan-3-ols, isoflavones, flavanones and anthocyanidins [46]. These six subgroups exhibit little differences in structure, such as the degree of (un-)saturation, and/or position of substituent groups [42,43].

A high proportion of flavonoids occur naturally as water-soluble glycosides [48]. Modifications to the hydroxylation patterns in the two aromatic rings may occur, generally at the flavanone or dihydroflavonol stage, and methylation, glycosylation, and dimethylallylation are also possible, increasing the range of compounds enormously [42,49]. Dihydroflavonols are intermediates in the conversion of flavanones into flavonols, and may also be known as flavanonols [42].

\subsection{Biosynthesis of Phenolic Compounds}

All phenolic compounds derive from phenylalanine (or tyrosine) and its precursor shikimic acid [49]. The shikimate pathway exists only in plants and microorganisms, but not in animals (Figure 3, encircled in green). The pathway begins with the formation of 3-deoxy-D-arabino-heptulosonic acid-7-phosphate (DAHP) by DAHP synthase (DAHPS) catalyzing an aldol condensation of phosphoenolpyruvate (PEP) and D-erythrose-4-phosphate [42,49].

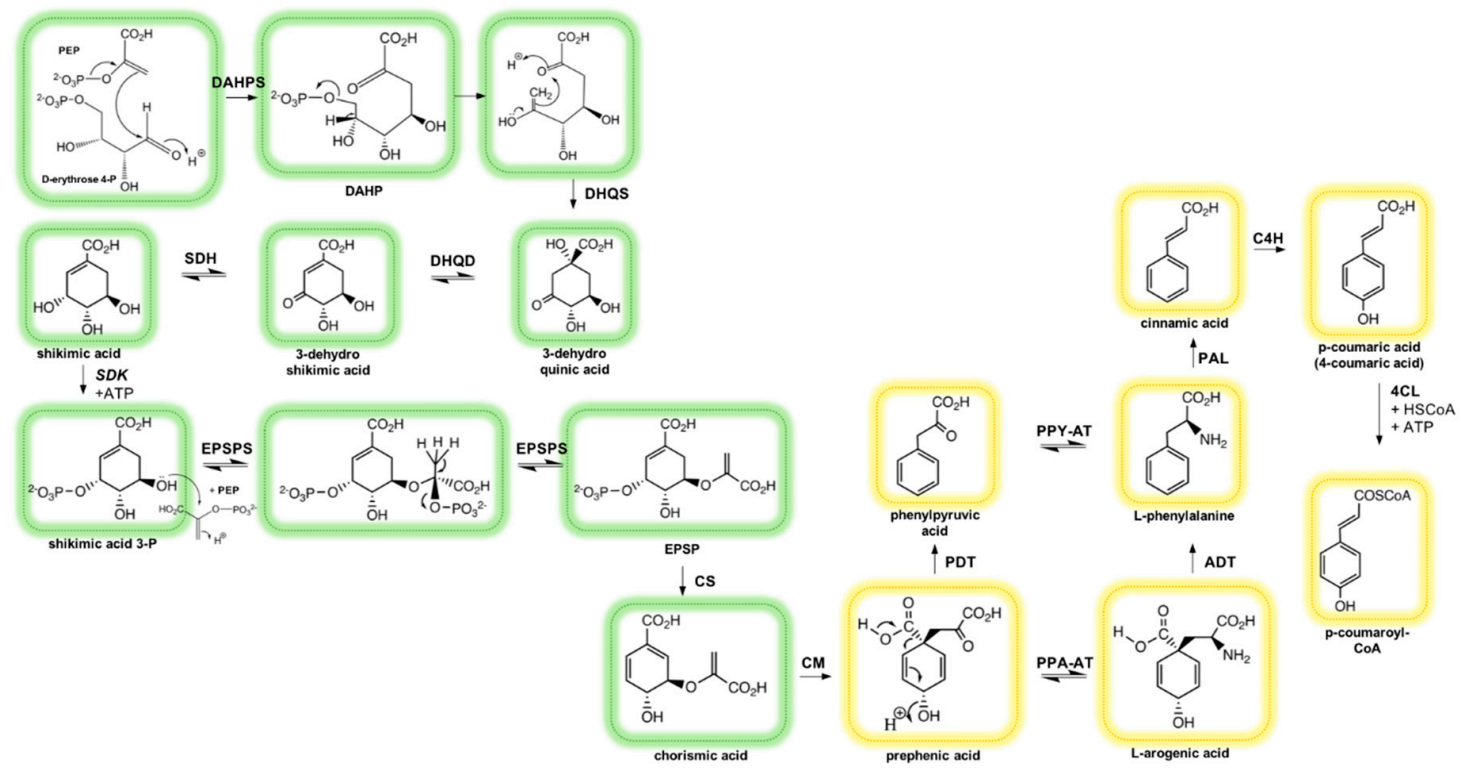

Figure 3. Interplay of shikimate and phenylpropanoid pathway. A detailed description can be found in the text. Shikimate pathway (encircled in green): DAHPS: 3-deoxy-D-arabino-heptulosonate-7-phosphate synthase; DHQS: 3-dehydroquinate synthase; DHQD: 3-Dehydroquinate dehydratase; SDH: Shikimate dehydrogenase; SDK: Shikimate kinase; EPSPS: 5-Enolpyruvylshikimate-3-phosphate synthase; CS: Chorismate synthase. Phenylpropanoid pathway (encircled in yellow): CM: Chorismate mutase; PPA-AT: Prephenate aminotransferase; PDT: Prephenate dehydratase; ADT: Arogenate dehydratase; PPY-AT: Phenylpyruvate aminotransferase; PAL: Phenylalanine ammonia lyase; C4H: Cinnamate-4-hydroxylase; 4CL: 4-coumarate:CoA ligase (Adapted from [49-51]).

Then, phosphoric acid is removed from DAHP via 3-dehydroquinate synthase (DHQS) which further undergoes an intermolecular aldol reaction producing 3-dehydroquinic acid. Shikimic acid is formed from 3-dehydroquinic acid via 3-dehydroshikimic acid by dehydration and reduction steps both enzymatically catalyzed (via 3-dehydroquinate dehydratase (DHQD) and shikimate dehydrogenase (SDH)).

The simple phenolic acids, protocatechinic acid (3,4-dihydroxybenzoic acid) and gallic acid (3,4,5-trihydroxybenzoic acid), can be formed from 3-dehydroshikimic acid by branch-point reactions, which involve dehydration and enolization, or, in the case of gallic acid, dehydrogenation and enolization $[42,45,49]$. Gallic acid may be synthetized by the same pathway as the other hydroxybenzoic 
acids, although the direct aromatization of dehydroshikimic acid is considered to represent the main pathway. Gallic acid is the biosynthetic precursor structure to hydrolysable tannins and ellagic acids [42,45]. The enzymes believed to be involved mainly in this pathway are shikimate dehydrogenase and 5-dehydroshikimate dehydrogenase, although it is still under discussion whether other enzymes or pathways might be involved as well in the synthesis of gallic acid [42].

Shikimate is further converted to shikimate-3-phosphate in a phosphorylation reaction. The enzyme 5-enolpyruvylshikimate-3-phosphate synthase (EPSPS) incorporates a molecule of phosphoenolpyruvate (PEP) in shikimate-3-phosphate forming 5-enolpyruvylshikimate-3-phosphate (EPSP) [49]. The latter is subsequently converted by chorismate synthase (CS) to chorismate through a 1,4-elimitation of phosphoric acid.

From chorismate, phenylalanine (Phe) can be formed following the phenylpropanoid pathway, although this pathway does not belong to the shikimate pathway (Figure 3, encircled in yellow). Nevertheless, Phe is an intermediate for the phenylpropanoid pathway [42,49]. In plants, chorismate is converted into prephenate through an intramolecular rearrangement via chorismate mutase (CM). Subsequently, prephenic acid can be decarboxylated by prephenate dehydratase (PDT) into phenylpyruvic acid (losing a hydroxyl group at the same time), which in turn undergoes a transamination via phenylpyruvate aminotransferase (PPY-AT) resulting in L-Phe. In the presence of a dehydrogenase, prephenic acid can undergo one more decarboxylative aromatization with retention of the hydroxyl group, leading to the formation of 4-hydroxylphenylpyruvic acid that would be an intermediate for tyrosine biosynthesis (not shown). From 4-hydroxylphenylpyruvic acid another transamination can occur, giving rise to Tyrosine (Tyr) and Tryptophan (Trp), further intermediates for the phenylpropanoid pathway. If prephenic acid undergoes transamination before a decarboxylative aromatization occurs, L-arogenic acid is formed catalyzed by prephenate aminotransferase (PPA-AT). Phe and Tyr can be synthetized as well from arogenic acid through arogenate dehydratase (ADT) and arogenate dehydrogenase (ADH, not shown), respectively [42,49].

The phenylpropanoid pathway generates the basic structure for the formation of flavonoids, hydroxycinnamic acids, coumarins, and stilbenes among other phenolics. This pathway starts with the deamination of L-Phe into cinnamic acid by the phenylalanine ammonia lyase (PAL) enzyme. $\mathrm{P}$-coumaric acid is subsequently originated from the hydroxylation of cinnamic acid mediated by cinnamic acid-4-hydroxylase $(\mathrm{C} 4 \mathrm{H})[42,49]$. Cinnamic acids can be synthetized as well from p-coumaric acid through hydroxylation and methylation reactions. Both cinnamic acid and p-coumaric acid can exist in plants in their free or esterified form. Hydroxybenzoic acids can be obtained by double bound cleavage of cinnamic acid and loss of two carbons from their side chain. The phenylpropanoid pathway ends with the conversion of p-coumaric acid in p-coumaroyl-Coenzyme-A (CoA) by the enzyme 4-coumarate:CoA ligase (4CL). P-coumaroyl-CoA will act as an intermediate in the biosynthesis of several other classes of phenolic compounds, such as flavonoids [42,49].

Flavonoid biosynthesis (Figure 4) starts with condensation of three molecules of malonyl-CoA with p-coumaroyl-CoA to form $4,2^{\prime}, 4^{\prime}, 6^{\prime}$-tetrahydroxychalcone (naringenin chalcone) catalyzed by chalcone synthase (CHS) [52]. This is an iterative multistep reaction generating linear di-, tri-, and tetra-ketide-CoA intermediates as well as a cyclic and prochiral coumaryl-trione intermediate [52,53]. In addition, leguminous plants express the enzyme chalcone reductase (CHR) reacting to the intermediates produced by CHS forming 4,2', $4^{\prime}$-trihydroxychalcone (deoxychalcone) [52]. Deoxychalcone is the start point for the enzymatic conversion to 6 '-deoxychalcone (isoliquiritigenin) catalyzed by CHS in addition to polyketide reductase (PKR) [42]. The resulting products of the two branches (naringenin chalcone and isoliquiritigenin) have the basic flavonoid structure C6-C3-C6. In the following step a ketoester will be formed by a Diekmann condensation (a specific Claisen cyclization) supported by chalcone isomerase (CHI) [49]. CHI enables the formation of the six atom O-heterocycle, which results in the formation of flavanones called naringenin if the educt was naringenin chalcone or liquiritigenin coming from isoliquiritigenin [42]. Different flavonol hydroxylases subsequently convert naringenin in dihydrokaempferol, dihydromyricetin and dihydroquercetin, which differ in their number of hydroxyl 
groups. Flavanones are also precursor molecules to isoflavones, belonging to another subclass of flavonoids, the isoflavonoids (not shown in Figure 4) [49]. These compounds present a slightly different chemical structure in which ring B has migrated to the adjacent C3 carbon of the heterocycle in a process that is enzymatically catalyzed and quite rare in nature [49].

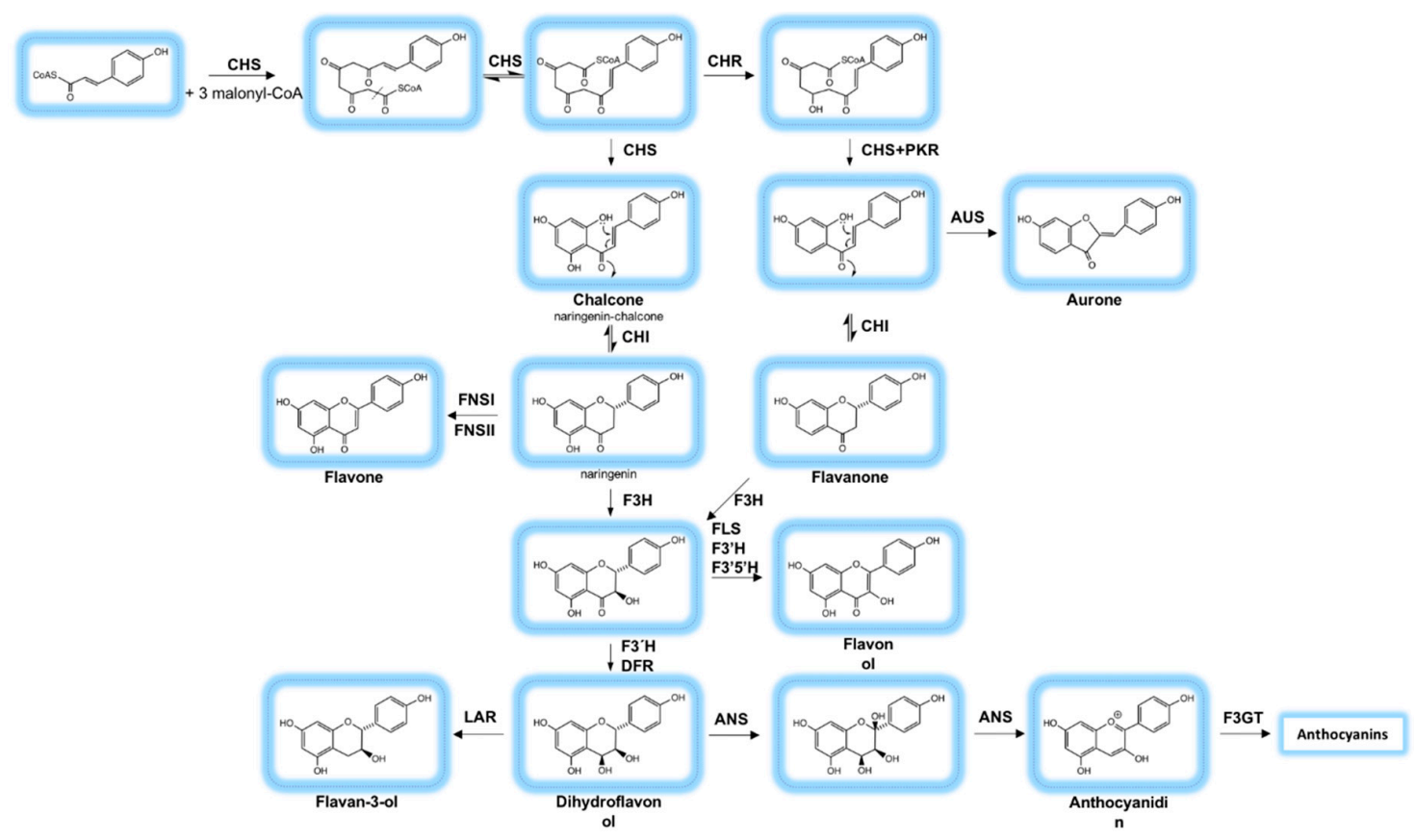

Figure 4. Biosynthesis of flavonoids via the flavonoid pathway. A detailed description can be found in the text. CHS: Chalcone synthase; CHR: Chalcone reductase; PKR: Polyketide reductase; CHI: Chalcone isomerase; AUS: Aurone synthase; FNSI: Flavone synthase I; FNSII: Flavone synthase II; F3H: Flavanone-3-hydroxylase; FLS: Flavonol synthase. Anthocyanin pathway: F3'H: Flavonoid-3'-hydroxylase; F3'5'H: flavonoid-3', 5'-hydroxylase; DFR: Dihydroflavonol-4-reductase; LAR: leucoanthocyanidin reductase; ANS: Anthocyanidin synthase; F3GT: UDP-Glc flavonoid 3-O-glucosyltransferase (Adapted from references [49-51]).

Flavone synthase (FNS) converts flavanones into flavones, and through another pathway, flavanones are converted to flavanonols by the joint action of flavanone-3-hydroxylase ( $\mathrm{F} 3 \mathrm{H})$, flavonoid-3'-hydroxylase $\left(\mathrm{F}^{\prime} \mathrm{H}\right)$, flavonoid- $3^{\prime}, 5^{\prime}$-hydroxylase $\left(\mathrm{F}^{\prime} 5^{\prime} \mathrm{H}\right)$ and flavonol synthase (FLS) [42]. Intermediates of these conversions, the dihydroflavonols, can give rise to flavandiols (leucoanthocyanidins) via dihydroflavonol-4-reductase (DFR) [42,49]. Flavandiols are the precursors of two further subclasses named flavan-3-ols and anthocyanidins. The formation of flavan-3-ols from flavandiols is mediated by the enzyme leucoanthocyanidin reductase (LAR) [42].

Anthocyanin biosynthesis starts when the dihydroflavonols are converted by DFR into the colorless anthocyanidin compounds leucocyanidin, leucopelargonidin and leucodelphinidin [42,49]. Removal of hydrogens and the induction of a double bond of ring $\mathrm{C}$ at $\mathrm{C} 2$ and $\mathrm{C} 3$ positions is mediated by anthocyanidin synthase (ANS) and the resulting ring $C$ is a pyrilium kation [42]. From this reaction occurs the formation of the colored anthoyanidins, namely, cyanidin, pelargonidin, and delphinidin [49]. The addition of different chemical groups to anthocyanidins, e.g., methylation or coumaroylation, result in the stabilization of the compound and thereby a stabilization of the color as seen in fruits [42]. The enzyme UDP-glucose flavonoid 3-O-glucosyltransferase (F3GT) is responsible for converting the free anthocyanidin into its glycosylated form (anthocyanin) by the addition of a sugar unit $[42,44,49]$. The most common glycosylation site is the 3-hydroxyl position often using a glucose residue [43] (notice in Figure 2 the general nomenclature for the numbering of flavonoid carbons). However, if there is already a sugar unit present at the 3-hydroxyl position, the next position, were glycosylation 
can occur, will be the 5-hydroxyl position [43]. Other sugars can be substitutes as well, e. g. arabinose, although glucose is the most common one. Also, anthocyanins can be acetylated, where an organic acid is esterified to the sugar [42]. The color of anthocyanidins varies with the $\mathrm{pH}$, for example, these compounds are often red at a $\mathrm{pH} 3.5$. As the $\mathrm{pH}$ increases they start becoming colorless and then shift towards blue $[44,48]$. Anthocyanins accumulate in the vacuole of the cell, and are often abundant in cells closer to the epidermis of the fruit [48]. Some enzymes can convert anthocyanidins into the correspondent flavan-3-ols in the biosynthesis of condensed tannins [42]. These resulting flavan-3-ols can polymerize to also form proanthocyanidins [54,55].

In plants, flavonoids may occur in the forms of O- or C-glycosides, with O-glycosides being the most usual structures [43]. Glycosylation can occur in positions 3-, 5- and 7- making the structures more water soluble, and allowing their storage in the vacuoles [42,45]. The most usual sugars involved in glycoside formation are glucose, galactose, rhamnose, xylose, arabinose and disaccharides such as rutose [43].

\subsection{Genes and Regulation of the Biosynthesis of Phenolic Compounds in General}

As described in the previous section, a great variety of enzyme-catalyzed reactions are involved in the phenolic and flavonoid biosynthesis. Nevertheless, only few of the involved genes in Capsicum annuum are known. Therefore, we will summarize here the actual knowledge of studies from other species mostly performed in Arabidopsis (Arabidopsis thaliana (L.) Heynh.), Petunia (Petunia hybrid (Sweet) D. Don ex W. H. Baxter), maize (Zea mays L.), and tomato (Solanum lycopersicum L.), and indicate those genes, that are already known.

Most of the involved enzymes known to date are thought to be located and to operate in the cell's cytosol [42,50]. In the various branches of the phenylpropanoid pathway, the most important enzymes include various transferases, reductases, membrane-bound cytochrome P450-dependent mono-oxygenases (P450s), and soluble non-heme dioxygenases. Figures 3 and 4 summarize the main biosynthetic enzymes involved in the shikimate, phenylalanine, and phenylpropanoid pathways.

Other enzymes are also involved in the hydroxylation, glycosylation and methylation of flavonoids. These structural modifications have as well an impact on the regulation of flavonoid biosynthesis, as alterations during biosynthesis can inhibit or turn the biosynthetic pathway in other directions [50].

Enzymes involved in these pathways are also believed to be organized in multi-enzymatic complexes associated with the endoplasmatic reticulum or anchored through P450 enzymes working in a synchronized, multistep way [50]. This would allow a channeling of the pathway in order to produce a specific flavonoid.

To better understand the regulation of the flavonoid biosynthesis pathway, various model species have been used as mentioned before to uncover genes involved in this complex pathway. Vermerris and Nicholson [42] briefly list a few examples of genes involved in the phenolic pathway, most of them identified in the aforementioned model species. Chalcone synthase (CHS) is encoded by At5g13930 in Arabidopsis [56], At3g55120 encodes for chalcone isomerase (CHI) [57], At3g51240 for flavanone-3-hydroxylase (F3H) [58] and At5g07990 for flavonoid-3'-hydroxylase (F3' $\mathrm{H}$ ) [59].

In maize the CHS gene is called COLORLESS1 (C1, Zm00001d052673) [60] as mutations in this gene result in loss of color, and F3'H was first described as PR1 (PURPLE/RED ALEURONE1, Zm00001d017077 [61]). Until today the analogous genes of CHI and F3H in maize are not described. In tomato some of the conserved genes were identified on the basis of gene ontology, like CHS, that is encoded at least twice, CHS1 (Solyc05g053550) and CHS2 (Solyc09g091510) [62], CHI, that exist as an analogue called CHI1 (Solyc05g010320) [63] and a closely related gene called CHIL (CHALCONE ISOMERASE-LIKE, Solyc05g052240) [64], F3H (Solyc02g083860) [65], and F3'H (Solyc03g115220) [64]. For the last two only one member was yet identified each in tomato.

Genes involved in the biosynthesis of anthocyanins were also studied. For example, At5g42800 encodes for DFR in Arabidopsis [66], in maize the ANTHOCYANINLESS1 (A1, GRMZM2G026930) [67] gene encodes for this enzyme, and in tomato this is Solyc02g085020 [68]. Formation of anthocyanidins 
by the glycosylation of anthocyanins is also enzyme catalyzed and regulated. In maize, F3GT is encoded by the BRONZE1 (Bz1, Zm00001d045055) [69] gene and in tomato by Solyc10g083440 [63]. The enzyme dihydrokaempferol-4-reductase reduces leucoanthocyanidins back to 2,3-trans-flavonol, a reaction that is important in the formation of condensed tannins, although the gene encoding for this enzyme is still not fully elucidated. It is believed that At1g61720 (BANYULS) in Arabidopsis encodes for an enzyme capable of using anthocyanidins as substrate to originating 2,3-cis-flavonols [70], a slightly different structure, while for the other species no analogues gene has been identified thus far. Nevertheless, the trans-flavonol is the basic structure for condensed tannins.

Transcriptional regulation is the most important tool for modulating flavonoid biosynthesis. Having a series of different branches inside the pathway coming from the same precursor but leading to different compounds makes this biosynthetic pathway very complex, requiring fine regulation [50]. Multiple genes are normally involved in such regulation along with different transcription factors (TFs). Therefore, the synthesis of flavonoids and other phenolic compounds can be regulated through a number of internal and external factors. The regulatory genes are involved in the expression of TFs belonging to the MYB-, basic helix-loop-helix (bHLH-), and/or WD-repeat protein families controlling flavonoid biosynthesis [71]. These TFs can enhance the expression of the structural genes involved in the pathway.

To date, the best studied part of regulation in flavonoid biosynthesis focuses on anthocyanins. Some of these genes were reviewed by [42]. Maize was the initial model species for analysis of the flavonoid biosynthesis pathway often based on maize seed color. For example, in maize, the genes RED COLOR (R) and BOOSTER (B) appear to be able to activate the F3GT-analogue of maize Bz1. Another gene, the Lc (red leaf color 1 ) gene, encodes a TF required for the expression of COLORLESS1 (C1) and $A 1$ (DFR) (both enzymes involved in the anthocyanidin pathway), while $A 1$ could as well be activated by B. In turn, $\mathrm{C} 1$ regulates the expression of $C 2, A 1, B z 1, B z 2$ (ZmGST) and $A 2$ (ZmANS) genes [42].

At5g35550 (TT2) [72], At4g09820 (TT8), At5g24520 (TTG1) [73], and At2g37260 (TTG2) [74,75] are some regulatory genes present in Arabidopsis. At5g24520 (TTG1) encodes for a protein with four WD40 repeats, At4g09820 (TT8) encodes for a protein important in the expression of DFR and BANYULS, At5g35550 encodes for a R2R3 MYB protein that works together with the protein expressed by At4g09820 (TT8) to regulate the expression of BANYULS. TTG2 encodes a TF characterized by the presence of a WRKYGQK amino sequence resembling a zinc finger motive. This TF can be called the WRKY factor and it is believed to be involved in the synthesis of condensed tannins [76].

Concerning the regulation of the biosynthetic genes in Capsicum species, some studies have been conducted. However, most of them are focused on anthocyanin biosynthesis regulation and use purple pepper varieties, whereas anthocyanin accumulation can be more easily seen.

Aguilar-Barragán et al. [77] studied the effects of different TFs (MYB and WD40) on the anthocyanin biosynthetic pathway in chili pepper fruits (Capsicum eximium). The silencing of both TFs decreased the anthocyanin accumulation in chili peppers as the expression of the genes encoding for $\mathrm{CHS}, \mathrm{CHI}$, $F 3^{\prime} 5^{\prime} H$, DFR, and F3GT was down regulated [77]. Two different cultivars of C. annuum L. fruits, "Árbol" and "Uvilla", were used to elucidate anthocyanin accumulation patterns [78]. The expression of $F 3^{\prime} 5^{\prime} H$, DFR, F3GT, and GLUTATHION S-TRANSFERASE (GST, probably involved in the sequestration of anthocyanins) showed a positive correlation with anthocyanin accumulation.

First interactions between MYB and MYC TF in anthocyanin accumulation were uncovered by Stommel et al. [79]. Both MYC transcripts and MYC protein levels were higher in Capsicum tissues that presented high anthocyanin contents. The transcription of the genes encoding for MYC and MYB was also substantially higher in pigmented fruits and flowers reinforcing that these TFs are strongly correlated with the accumulation or depletion of anthocyanins. However, this positive correlation could not be found in other types of tissues [79].

In a study from 2011, Li et al. [80] hypothesized that three R2R3-MYB homologs might be involved in anthocyanin accumulation in leaves, fruits and flowers of green hot pepper (cultivar "Haijiao"). Only CaMYB1 (GenBank: AF477956.1) and CaMYB2 (GenBank: AJ608992) clustered with MYB 
genes from other species in a phylogenetic analysis, while CaMYB3 (GenBank: EF222025) did not. Therefore, CaMYB3 was suggested to be a minor actor in the biosynthesis pathway. The expression of CaMYB1 and anthocyanin biosynthesis genes CHS, CHI, F3H, DFR, ANS and F3GT decreased with fruit ripening, suggesting that $\mathrm{CaMYB1}$ is in fact regulating anthocyanin synthesis during fruit maturation. The authors also reported that the expression of $C a M Y B 3$ decreased only slightly during fruit ripening. $C a M Y B 2$ showed high expression in flowers and a dramatically reduced expression in ripening fruits, while CaMYB1 showed only a weak expression in flowers. This is giving a hint, that both, CaMYB1 and CaMYB2 might regulate structural genes, as all analyzed structural genes of the flavonoid and anthocyanidin biosynthesis also showed a high expression in flowers of pepper [80].

In another study, the CaMYB2 TF was silenced by virus induced gene silencing in purple peppers [81]. This resulted in a repressed expression of the genes $C H S, C H I, F 3 H, F 3^{\prime} 5^{\prime} H, D F R, A N S$, F3GT, ANTHOCYANIN PERMEASE (ANP), and GST and a decreased anthocyanin accumulation in the leaves. Moreover, leaves were also more susceptible to Phytophthora capsici infection suggesting that CaMYB2 might also be involved in defense against pathogens. It was also demonstrated that CaMYB2 is involved in the activation of a complex built by an MYB TF, a basic helix-loop-helix (bHLH) MYC protein and WD40 protein (together MBW complex) [79]. The MBW complex is described to interact with the promoters of late structural genes and marginally with that of early structural genes [72] in the anthocyanidin biosynthesis. In addition, CaMYB2 also positively regulated MYC, so that the expression of the MYC locus in the silenced CaMYB2 environment was reduced [81]. However, in this study, the WD40 TF was negatively regulated by CaMYB2 [81], although the opposite was reported before [79]. Therefore, the results indicate that the regulatory network of MYB within the anthocyanin biosynthesis of different Capsicum species may vary [81].

Although the Capsicum annuum genome was finally published in 2014, the chromosomal location of flavonoid synthesis genes and associated regulatory genes is still not fully elucidated [82,83]. However in 2013, Wahyuni et al. [84] had already investigated flavonoid quantitative trait loci (QTLs) and proposed chromosomal locations for flavonoid synthesis related genes. For instance, the $C a-M Y B 12$ gene is located at chromosome 1 and a new QTL related to increased synthesis of naringenin chalcone was detected at the same region. Also, on chromosome 1 expression QTLs (eQTL) for CHS-1, CHS-2, CHI-2 and FLS were mapped. On chromosome 9, a metabolite QTL (mQTL) for naringenin chalcone was mapped, suggesting either that flavonoid regulation is a complex phenomenon involving different parts of the genome as eQTLs for CHS-1, CHS-2, CHI-1, CHI-2 and FLS-2 were also mapped on chromosome 9. An eQTL for FLS-2 was mapped at $162.1 \mathrm{cM}$ on chromosome 6 and was strongly associated with mQTLs for four flavone C-glycosides. Further, on chromosome 6 the CHI-4 locus at $176.8 \mathrm{cM}$ presented an eQTL for the CHI-4 gene, and this locus is associated with the expression of FLS-2 gene and with the flavone C-glycosides. This study showed that flavonoid QTL hotspots exist in the Capsicum genome and that the biosynthesis of these compounds is complex and involves a wide number of genes [84].

To bring more insights in the biosynthesis of flavonoids and its regulation in C. annuum, further investigations have to be performed.

\section{Phenolic Composition of Capsicum Annuum}

\subsection{Preparation and Measurement of Phenolic Compounds from Plants}

The accumulation of SM increases a crop's value as they can have a vast amount of applications, as mentioned before. Therefore, it is important to understand the chemical composition of Capsicum annuum in order to understand its bio-active potential, health-promoting effects as well as for increasing its value and applicability.

Phenolic and flavonoid contents are usually measured in plant extracts using methanol in varying concentrations as a solvent $[85,86]$, but other solvents can be used as well, such as ethanol, n-hexane, chloroform, acetone and many more [87]. The extraction can last from a few minutes to hours, will be 
performed with or without the help of ultrasonification, at different temperatures ranging from room temperature over $65^{\circ} \mathrm{C}$ up to boiling [88], and with or without an additional solid phase extraction step [89]. This results in almost incomparable data, as solvation of phenolic compounds will vary according to the used extraction method. In addition to the inconsistent preparation of the samples, in the following presentation data can be expressed either in dry weight (dw) or fresh weight (fw). Results expressed in dw are more precise since large weight fluctuations (e.g., between tissues) caused by differences in water content do not occur. This is particularly important when comparing different tissues like leaves and fruits that have a very different water content which contributes to the tissues "total weight". The heterogeneity of results reported and discussed in chapter 3.2 can partially be explained by this fact.

For the colorimetric determination of the total phenolic content (TPC), three different methods are widely used. The Folin-Ciocalteu reagent is a common reagent for determination of TPC [90]. The reagent produces a detectable colored complex when reacting with phenolic compounds, based on the transfer of an electron from an antioxidant substrate to the reagent complex in (often) alkaline medium. The color complex is measured at a wave length of $660 \mathrm{~nm}$, and quantification is based on comparison with a standard solution of a determined concentration of e.g., gallic acid resulting in gallic acid equivalents (GAE), or catechin resulting in catechin equivalents (CE). Nevertheless, the Folin-Ciocalteu reagent can interact as well with any other reducing substance. As most antioxidants present in plants are phenolic compounds, the intensity of the coloring can serve as an approximation for the total phenolic content. Besides the varying extract preparation, the initial concentration of the extract and the ratio with the reagent, as well as the incubation time will influence the results and make a comparison of results from different studies difficult to interpret.

An alternative is the antiradical activity assay based on the reduction of the 2,2-diphenyl1-picrylhydrazyl (DPPH) radical, which has a deep violet color with an absorption maximum at $520 \mathrm{~nm}[91,92]$. Neutralization of the radical by an antioxidant will change the color to colorless or pale yellow. This allows an optical monitoring, and results are sometimes shown in \% inhibition/DPPH reduction after a given time [93], antioxidant concentration required to reduce $50 \%$ of the DPPH present $\left(\mathrm{EC}_{50}\right.$ ) [94], $\mathrm{IC}_{50}$ (half maximal inhibitory concentration), antioxidant efficiency ( $\mathrm{AE}=1 / \mathrm{EC} 50$ $\times$ TEC50) (where TEC50 is the time needed to reach the steady state at EC50 concentration) [95], or expression of antioxidant activity as $\mu$ mol equivalents of standards such as vitamin C [96] or Trolox (6-hydroxy-2,5,7,8-tetramethylchroman-2-carboxylic acid) [97]. All of these presentations do not care about the reaction kinetic. In addition, many aspects during the implementation can affect the results, such as absolute and relative concentrations of DPPH and sample [98], solvent polarity and hydrogen bonding strength [99], $\mathrm{pH}$ [100], temperature [101], and oxygen. Therefore, a careful setup and internationally standardized protocols should be used, otherwise results of different origin cannot be compared [102].

In addition, ABTS (2,2'-azino-bis(3-ethylbenzothiazoline-6-sulphonic acid)) is commonly used in food chemistry to measure the antioxidant activity of food products, as it reacts in the presence of phenolic compounds, thiols and vitamin C. ABTS is a stable radical that presents a blue color absorbing at $734 \mathrm{~nm}$ when in its radical cation form (ABTS+) and is colorless in the neutral form [103]. Hydroxyl groups of phenolic compounds and thiols act as hydrogen donors, converting the blue-greenish ABTS+ cation to its neutral form and thereby causing a decrease in the absorption at $734 \mathrm{~nm}$. The antioxidant potential of the various antioxidants tested is compared to that of Trolox given as Trolox equivalent antioxidative capacity (TEAC) [103-105]. It is noteworthy that ABTS and DPPH radicals have different antioxidant potentials and reaction kinetics when reacting with phenolic compounds. During the reaction, the ABTS radical has to be formed initially, while DPPH is already a stabilized radical by itself. Furthermore, both have different molecular sizes and can have different affinities for other compounds that are present in the samples, like carbohydrates, lipids, proteins etc. Therefore, DPPH and ABTS assays follow different types of chemical reactions giving different and sometimes opposite results. 
Total flavonoid content (TFC) can be estimated with a colorimetric assay using aluminum chloride [106]. Briefly, aluminum chloride is capable of binding the 3- and 5-hydroxyl and 4-keto groups of flavonoids, forming a complex. The formation of this complex can be monitored by spectroscopy (UV and visible). The results are normally expressed as "a certain flavonoid" equivalents as different flavonoids can be used for calibration curves (luteolin, quercetin, naringin etc.). However, this method is relatively specific for flavonols and flavones.

Some authors like Kim et al. [107], Marin et al. [108] and Howard et al. [109] used liquid chromatography to determine the total flavonoid content, based on the addition of the different (few) flavonoid groups identified. This can be a very imprecise estimation of the true flavonoid amount since the identification and quantification is made by comparison with two or three commercially available flavonoid standards (usually aglycones) which do not fully represent the total amount of flavonoids that might exist in pepper.

\subsection{Total Phenolic and Flavonoid Content in Capsicum}

The general phenolic content and antioxidant properties of $C$. annuum fruits, leaves and other plant parts are given in Table 1. It is revealed that fruits have been much better studied than any parts of the plant in terms of phenolic metabolites. Further, only one chalcone was reported to date in pepper fruits: phloretin dihexoside, a dihydrochalcone and possibly a diglucoside of phloretin [110].

Table 1. Global antioxidant activity and phenolic content of Capsicum annuum L. in fruits, leaves and other tissues.

\begin{tabular}{|c|c|c|c|c|c|c|}
\hline \multirow[t]{2}{*}{ Parameter } & \multicolumn{4}{|c|}{ Content } & \multirow[t]{2}{*}{ Content Expressed In } & \multirow[t]{2}{*}{ Reference } \\
\hline & $\begin{array}{c}\text { Fruit } \\
\text { (Pericarp) }\end{array}$ & Leaves & Stems & Other & & \\
\hline \multicolumn{7}{|l|}{ Phenolic Content } \\
\hline \multirow[t]{4}{*}{ Total Phenolic Content } & $6.97-12.19$ & - & - & - & mg CE/g f.w & [108] \\
\hline & $6.92-7.32$ & 17.14 & - & - & $\mathrm{mg} \mathrm{CE} / \mathrm{g} \mathrm{dw}$ & [107] \\
\hline & $1.03 *$ & - & - & - & mg GAE/g fw & [111] \\
\hline & 52.27 & - & 71.34 & $\begin{array}{c}64.07 \\
\text { (placenta) }\end{array}$ & $\mathrm{mg}$ GAE/g dw & [112] \\
\hline \multirow[t]{4}{*}{ Total Flavonoid Content } & $0.017-0.2024$ & - & - & - & $\mathrm{mg} / \mathrm{g} \mathrm{fw}$ & {$[108,109]$} \\
\hline & $0.00366-0.0054$ & 0.0206 & - & - & $\mathrm{mg} / \mathrm{g} \mathrm{dw}$ & [107] \\
\hline & 46.71 & - & 69.84 & $\begin{array}{c}58.96 \\
\text { (placenta) }\end{array}$ & $\mathrm{mg}$ NAE/g dw & [112] \\
\hline & 0.3864 & - & - & - & $\mathrm{mg} \mathrm{QE} / \mathrm{g} \mathrm{fw}$ & [111] \\
\hline Total O-glycosyl-flavones & $1.00-9.43$ & - & - & - & $\mathrm{mg} / 100 \mathrm{~g} \mathrm{fw}$ & [108] \\
\hline Total C-glycosyl-flavones & $0.84-2.45$ & - & - & - & $\mathrm{mg} / 100 \mathrm{~g} \mathrm{fw}$ & [108] \\
\hline Total hydroxyl-cinnamics & $0.33-1.99$ & - & - & - & $\mathrm{mg} / 100 \mathrm{~g} \mathrm{fw}$ & [108] \\
\hline \multicolumn{7}{|l|}{ Antioxidant Activity } \\
\hline $\begin{array}{l}\text { Radical scaveng-ing activity } \\
\text { (RSA) }\end{array}$ & $17.32-48.95$ & - & - & - & TEAC/kg dw & [113] \\
\hline \multirow[t]{3}{*}{ (N) } & $15.40-286.23$ & 463.23 & - & - & $\begin{array}{l}\mathrm{IC}_{50} \mu \mathrm{g} 80 \% \text { EtOH } \\
\text { extract }(\mathrm{v} / \mathrm{v}) / \mathrm{mL}\end{array}$ & {$[107]$} \\
\hline & - & $49.2-62.2$ & - & - & $\mathrm{IC}_{50} \mu \mathrm{g} / \mathrm{mL}$ & [114] \\
\hline & $60.41 *$ & - & - & - & $\%$ of inhibition & [111] \\
\hline \multirow[t]{3}{*}{ ABTS } & $55.23-118.00$ & 68.67 & - & - & $\begin{array}{l}\mathrm{IC}_{50} \mu \mathrm{g} 80 \% \text { EtOH } \\
\text { extract(v/v)/mL }\end{array}$ & [107] \\
\hline & - & $26.2-33.7$ & - & - & $\mathrm{IC}_{50} \mu \mathrm{g} / \mathrm{mL}$ & [114] \\
\hline & $34.44 *$ & - & - & - & $\mu \mathrm{M}$ TEAC/g fw & [111] \\
\hline$\beta$-carotene bleaching & $42.75-66.98$ & - & - & - & $\%$ of inhibition & [109] \\
\hline
\end{tabular}

Stems and other parts of the plant (like placenta) have not been thoroughly studied, although leaves obtained some more attention. Nevertheless, the knowledge of the TPC and TFC in these pepper tissues will increase our understanding of the secondary metabolism in Capsicum.

TPC of C. annuum fruits ranges between $6.97-12.19 \mathrm{mg} \mathrm{CE} / \mathrm{g} \mathrm{fw}$ [108] or is around $1.03 \mathrm{mg} \mathrm{GAE} / \mathrm{g}$ $\mathrm{fw}$ [111], depending on the assay used to determine it. Mudrić and collaborators [113] compared 
the radical scavenging activities of different Capsicum cultivars harvested at different sites and years using the DPPH method and obtained variations between 17.32-48.95 mmol TEAC/ $\mathrm{kg} d w$, confirming that cultivar and harvest year have an influence on the chemical properties of Capsicum annuum [113]. In the same study the TPC also ranged from 7.03-14.92 $\mathrm{g} \mathrm{GAE} / \mathrm{kg} \mathrm{dw}$, variance occurring once more between two different cultivars. The authors also reported differences in TPC and radical scavenging activities between the same cultivar harvested in different years (data not shown). According to Kim et al. [107], Capsicum leaves had a TPC of $17.14 \mathrm{mg} \mathrm{CE} / \mathrm{g} \mathrm{dw}$, whereas the fruits ranged from 6.92-7.32 mg CE/g dw (difference between green and red fruits respectably), a value about 3 times lower than in the leaves. Chen et al. [112] reported a slightly higher amount of TPC in the stems than in the fruits, 71.34 versus $52.27 \mathrm{mg}$ GAE/g dw and similar results were obtained for total flavonoid content. In anti-inflammatory tests performed with mice, Chen et al. [112] also reported that the solvent of the extract influences as well the therapeutic effect, from almost useless to effective, although not comparable with dexamethasone treatment. In addition, Kim et al. [107] reported that the leaves ethanolic extract has a higher antioxidant activity than extracts from fruits, in terms of DPPH inhibition activity, although the same was not seen in the ABTS assay.

Besides, flavonoids do not represent a high percentage of Capsicum weight. In a study of Marín et al. [108], the highest value reported is $0.02 \%$ of the fruit's fw. In the same study, the total flavonoids, total O-glycosylflavones and total C-glycosylflavones were assessed in four fruit maturity states (from immature green, to green, immature red and red) in the variety "Vergasa". The authors reported that these values varied according to maturity stage, being higher when the fruit was in the immature state and decreased as the fruit went from green to red ripe state, suggesting that a change in the fruit's flavonoid composition occurs during fruit ripening [108]. Howard et al. [109] reported that the total flavonoid content varies not only with the maturity stage, but also with the cultivar (for example, one of the cultivars studied, "Inferno", presented a high flavonoid content in both immature and mature states). The authors reported the same effect in the amount of total hydroxycinnamics, which seemed to decrease with fruit development.

Kim et al. [114] focused only on the antioxidant potential and phenolic compounds of the leaves of three different cultivars of Capsicum annuum: "Blackcuban", "Hongjinju", and "Yeokgang-hongjanggun". The antioxidant activity measured either through the ABTS assay or the DPPH method revealed that the values could vary significantly depending on the cultivar. In the same study the absolute amount of nine phenolic compounds was assessed and also showed variations between the cultivars, at least for some of the compounds [114].

Medina et al. [111] evaluated the antioxidant activity of pepper from different cultivars using both the ABTS and the DPPH method. The values obtained for bell pepper (sweet varieties of Capsicum annuum) were $34.44 \mu \mathrm{M}$ of TEAC/g fw for the ABTS assay and $60.41 \%$ of inhibition for the DDPH assay. In both assays, the results varied significantly according to the cultivar of pepper tested, for instance, "Caribe" and "Bell" were the cultivars that showed highest antioxidant activity in both assays. The antioxidant activity of fresh pepper fruits was assessed by Howard et al. [109] based on their peroxyl radical quenching properties and expressed in $\%$ of inhibition of $\beta$-carotene bleaching. Once more the results varied depending on the cultivar and maturity stage.

All these findings suggest that $C$. annuum has a different chemical profile and bio-active potential in leaves and fruits according to the cultivar, leading to significant variations within the species. The harvest year and ripening stage affect the chemical composition of the fruits as well. In addition, it should be noticed that the overall concentration of antioxidative agents and phenolic content did not vary a lot between fruits and leaves. It is also possible to conclude that other parts of the plant, for instance stems, have a high quantity of bio-active compounds as well.

\subsection{Quantification of Flavonoids in Capsicum}

When it comes to identification and quantifying phenolic compounds in various parts of the Capsicum plant, once more the main focus has been given to the fruits. Table 2 shows the 
different phenolic compounds that were identified and quantified in Capsicum annuum using liquid chromatography coupled to a mass spectrometry (LC-MS). Fruits are much more well studied, although in the cases that different parts of the plant were used for the quantification it is possible to see that other organs have considerable amounts of phenolics [107,112,115].

Table 2. Quantification of phenolic compounds from Capsicum annuum L. (a-content expressed in $\mathrm{mg} / \mathrm{kg} \mathrm{fw}$; $\mathrm{b}$-content expressed in $\mathrm{mg} / \mathrm{kg} \mathrm{dw}$; fresh weight (fw); dry weight (dw) ID—Identified but not quantified).

\begin{tabular}{|c|c|c|c|c|c|}
\hline & \multicolumn{4}{|c|}{ Identified In } & \multirow[t]{2}{*}{ Reference } \\
\hline & Fruit & Leaves & Stems & Other & \\
\hline Class of Phenolic Compounds & a & a & a & a & \\
\hline \multicolumn{6}{|l|}{ Phenolic acids } \\
\hline Quinic Acid & ID & - & - & - & [116] \\
\hline \multicolumn{6}{|l|}{ Hydroxybenzoic acids } \\
\hline Gallic acid & 2.53-1013.0 & - & - & - & {$[111,113,116,117]$} \\
\hline 1-O-galloyl- $\beta$-D-glucose & ID & - & - & - & [116] \\
\hline Protocatechuic acid & $0.29-0.83$ & - & - & - & [113] \\
\hline \multirow[t]{2}{*}{ p-Hydroxybenxoic acid } & $420^{\mathrm{b}}$ & - & - & $\begin{array}{c}260^{\mathrm{b}} \\
\text { (placenta) }\end{array}$ & [112] \\
\hline & $2.88-6.27$ & - & - & - & [113] \\
\hline p-Hydroxyphenylacetic acid & $0.41-1.77$ & - & - & - & [113] \\
\hline p-Hydroxybenzoic acid $\beta$-glucoside & ID & - & - & - & [110] \\
\hline \multirow[t]{2}{*}{ Vanillic acid } & - & - & $130^{\mathrm{b}}$ & $\begin{array}{c}1020^{\mathrm{b}} \\
\text { (placenta) }\end{array}$ & [112] \\
\hline & $3.07-13.29$ & - & - & (P) - & [113] \\
\hline Vanillic acid glucoside & 4.02 & - & - & - & [118] \\
\hline $\begin{array}{l}\text { Vanillic-acid-1-O- } \beta \text {-D-gluco-pyranosylester } \\
\text { Hydroxycinnamic acids }\end{array}$ & ID & - & - & - & {$[110,116]$} \\
\hline \multirow[t]{2}{*}{ Caffeic acid } & $1320^{\mathrm{b}}$ & - & - & $\begin{array}{c}120^{\mathrm{b}} \\
\text { (placenta) }\end{array}$ & [112] \\
\hline & $0.55-13.7$ & - & - & - & {$[108,111,113]$} \\
\hline Hydrocaffeic acid & 3.03 & - & - & - & [118] \\
\hline Caffeoyl glucoside & 2.59 & - & - & - & [118] \\
\hline 5-O-Caffeoylquinic acid & $0.36-23.33$ & $260-360$ & - & - & {$[113,114]$} \\
\hline 5-O-Caffeoylquinic acid methyl ester & - & $10-340$ & - & - & [114] \\
\hline 5-O-Caffeoylquinic acid butyl ester & - & 20 & - & - & [114] \\
\hline Caffeic acid-4-O- $\beta$-D-glucopyranoside & ID & - & - & - & [110] \\
\hline 1-O-Caffeoyl- $\beta$-D-glucopyranoside & ID & - & - & - & [110] \\
\hline Caffeoyl-O-hexoside & ID & - & - & - & [119] \\
\hline 2-Caffeoyl-L-tartaric acid & ID & - & - & - & [116] \\
\hline 4-O-caffeoylquinic acid & ID & - & - & - & [116] \\
\hline \multirow[t]{2}{*}{ Chlorogenic acid } & $1560^{\mathrm{b}}$ & - & $3820^{b}$ & $\begin{array}{c}230^{\mathrm{b}} \\
\text { (placenta) }\end{array}$ & [112] \\
\hline & $2-17.9$ & - & - & - & {$[111,117]$} \\
\hline \multirow[t]{2}{*}{ p-Coumaric acid } & $4560^{\mathrm{b}}$ & - & $2980^{\mathrm{b}}$ & $\begin{array}{c}820^{\mathrm{b}} \\
\text { (placenta) }\end{array}$ & [112] \\
\hline & $0.09-6.97$ & - & - & Prest & {$[113,118]$} \\
\hline Coumaroyl quinic acid & ID & - & - & - & [116] \\
\hline p-Coumaryl tyrosine & 6.81 & - & - & - & [118] \\
\hline p-Coumaryl glycolic acid & 6.47 & - & - & - & [118] \\
\hline trans- $p$-coumaroyl- $\alpha$-D-gluco-pyranoside & $0.5-1.0$ & & & & [108] \\
\hline \multirow[t]{2}{*}{$\begin{array}{l}\text { Ferulic acid } \\
\text { Fis }\end{array}$} & $120^{\mathrm{b}}$ & - & - & - & [112] \\
\hline & $2.18-12.45$ & - & - & - & [113] \\
\hline Feruloyl-O-glucoside & 2.5 & - & - & - & [119] \\
\hline Feruloyl hexoside & $32-53.4$ & - & - & - & [120] \\
\hline Feruloyl- $\beta$-D-glucose & ID & - & - & - & [116] \\
\hline trans-feruloyl- $\alpha$-D-gluco-pyranoside & $0.9-1.0$ & & & & {$[108]$} \\
\hline trans-p-feruloyl- $\beta$-D-gluco-pyranoside & $84-359^{b}$ & - & - & - & {$[121,122]$} \\
\hline Syringic acid & $0.66-1.21$ & - & - & - & [113] \\
\hline Sinapic acid & $0.45-1.89$ & - & - & - & [113] \\
\hline Sinapoyl hexoside & $65.0-72.4$ & - & - & - & {$[120]$} \\
\hline trans-sinapoyl- $\alpha$-D-gluco-pyranoside & $1.4-3.0$ & - & - & - & [108] \\
\hline trans-p-sinapoyl- $\beta$-D-gluco-pyranoside & $74-419^{\mathrm{b}}$ & - & - & - & {$[121,122]$} \\
\hline Cinnamic acid & $0.03-0.24$ & - & - & - & [113] \\
\hline \multicolumn{6}{|l|}{ Coumarins } \\
\hline Hydroxycoumarin & 2.42 & - & - & - & [118] \\
\hline Daphnetine (7,8-Dihydroxycoumarin) & 16.29 & - & - & - & [118] \\
\hline Aesculin (Esculetin-6- $\beta$-D-glucoside) & $0.16-0.20$ & - & - & - & [113] \\
\hline Umbelliferone (7-hydroxycoumarin) & $10.66-14.61$ & - & - & - & [113] \\
\hline
\end{tabular}


Table 2. Cont

\begin{tabular}{|c|c|c|c|c|c|}
\hline & \multicolumn{4}{|c|}{ Identified In } & \multirow[t]{2}{*}{ Reference } \\
\hline & Fruit & Leaves & Stems & Other & \\
\hline Class of Phenolic Compounds & a & a & a & a & \\
\hline Phloretin dihexoside & ID & - & - & - & [110] \\
\hline \multicolumn{6}{|l|}{ Flavonoids } \\
\hline Flavonols & & & & & \\
\hline Quercetin & $3.29-783.83$ & - & - & - & {$[107,109,113,117,118,123]$} \\
\hline Quercetin-3-O-hexoside & 13.5 & - & - & - & [120] \\
\hline Quercetin rhamnoside & 82.60 & - & - & - & [118] \\
\hline Quercetin dihexoside & ID & - & - & - & [110] \\
\hline Quercitrin (Quercetin-3-O-rhamnoside) & $0.5-1501.8$ & - & - & - & {$[108,117,119,120]$} \\
\hline Quercetin-3-O-glucoside-7-O-rhamnoside & ID & - & - & - & {$[84]$} \\
\hline Quercetin-3,7-di-O- $\alpha$-L-rhamno-pyranoside & ID & - & - & - & [110] \\
\hline Quercetin-3,7-diglucuronide & ID & - & - & - & [116] \\
\hline Quercetin-3-rhamnopyranoside & ID & - & - & - & [110] \\
\hline Quercetin-3'-O- $\beta$-D-gluco-pyranoside & ID & - & - & - & [110] \\
\hline Quercetin- $4^{\prime}-\beta$-D-glucopyranoside & ID & - & - & - & [110] \\
\hline Quercetin-3-O- $\alpha$-L-rhamno-pyranoside & $113-993^{b}$ & - & - & - & {$[121,122]$} \\
\hline $\begin{array}{l}\text { Quercetin-3-O- } \alpha \text {-L-rhamnopyranoside- } \\
\text { 7-O- } \beta \text {-D-glucopyranoside }\end{array}$ & ID & - & - & - & [121] \\
\hline $\begin{array}{l}\text { Quercetin-3-O-(6'-O-acetyl)- } \\
\beta \text {-D-glucopyranoside }\end{array}$ & ID & - & - & - & [116] \\
\hline Hyperoside (Quercetin-3-O-galactoside) & $1.81-27.28$ & - & - & - & [113] \\
\hline Kaempferol-pentosyldihexoside & 42.1 & - & - & - & [120] \\
\hline Kaempferol-O-pentosyldihexoside & 1.3 & - & - & - & [119] \\
\hline Kaempferol-7, $4^{\prime}$-dimethoxy-8-butyryl ester & ID & - & - & - & [116] \\
\hline Myricetin & $2280^{b}$ & - & - & $\begin{array}{c}1380^{\mathrm{b}} \\
\text { (placenta) }\end{array}$ & [112] \\
\hline \multicolumn{6}{|l|}{ Flavan-3-ols } \\
\hline \multirow[t]{2}{*}{ Catechin } & - & - & $30^{b}$ & - & [112] \\
\hline & $1.1-36.8$ & - & - & - & [111] \\
\hline Epicatechin & $1-79.3$ & - & - & - & [111] \\
\hline \multicolumn{6}{|l|}{ Flavones } \\
\hline Dihydroxyflavone-O-hexoside & 3.1 & - & - & - & [119] \\
\hline Chrysoeriol-6,8-di-C-hexoside & ID & - & - & - & [124] \\
\hline Apigenin & 1.38 & - & - & - & [113] \\
\hline Apigenin-7-O-glucopyranoside & ID & - & - & - & [124] \\
\hline Apigenin-C-pentosyl-C-hexoside & $5.5-7.4$ & - & - & - & [120] \\
\hline Apigenin-6,8-di-C-hexoside & ID & - & - & - & [84] \\
\hline Apigenin-6-C-pentoside-8-C-hexoside & ID & - & - & - & {$[84]$} \\
\hline Vicenin 2 (Apigenin-6,8-di-C-glucoside) & 12.7 & - & - & - & [120] \\
\hline Apiin (Apigenin-7-O-apioglucoside) & $0.27-0.43$ & - & - & - & [113] \\
\hline $\begin{array}{l}\text { Apigenin-7-O- } \beta \text {-D-apiofuranosyl } \\
(1 \rightarrow 2)-\beta-D \text {-glucopyranoside }\end{array}$ & ID & $6-3530$ & - & - & {$[110,114]$} \\
\hline Apigenin-8-C-glucoside & ID & - & - & - & [116] \\
\hline $\begin{array}{l}\text { Apigenin- } 8-C-\alpha \text {-L-arabinoside- } \\
6-C-\beta \text {-D-glucoside }\end{array}$ & ID & - & - & - & [110] \\
\hline
\end{tabular}


Table 2. Cont.

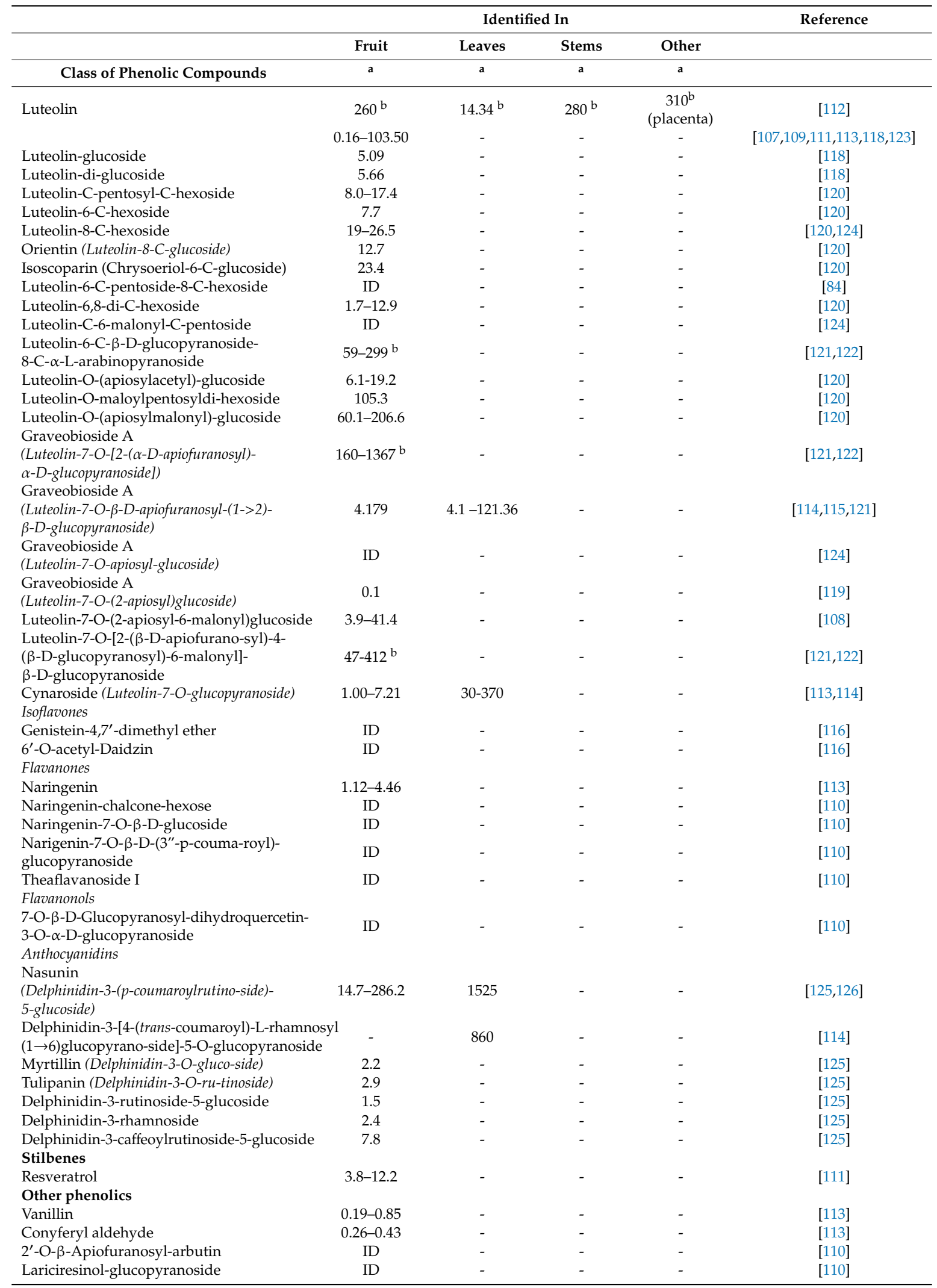

Kashiwagi et al. [115] and Kim et al. [114] showed that pepper leaves have a higher amount of quercetin, luteolin and graveobisode A than the fruits. In addition, for the cited studies different cultivars of Capsicum annuum L. have been used, which justifies the ranges reported for the compounds 
quantified. Morates-Soto et al. [110] used the cultivars "Italian sweet" (green), "Lamuyo" (yellow) and "California wonder" (red). Mokhtar et al. [118] used the "Biskra" fruits variety and Park et al. [119] used the "Chelsea" fruit cultivar. Marín et al. [108] analyzed the "Vergasa" cultivar at four different fruit maturity states. Sadilova et al. [125] analyzed the anthocyanins present in a violet pepper variety. Mudric et al. [113] studied different cultivars and varieties of Capsicum ("Lemeška" sweet, "Lemeška" hot, "Lemeška" semi-hot and "Lakošnicka") harvested in different years. Ogunruku et al. [117] analyzed the variety "Grossum" in ripe and unripe maturity stages. Materska et al. [121] studied two hot pepper cultivars, "Cyklon"and "Bronowicka Ostra", and two semi hot cultivars, "Tajfun" and "Tornado", at two different maturity states. Tundis et al. [127] used the cultivars "Acuminatum" small and "Cerasiferum" and Moreno-Ramírez et al. [116] studied the chili variety "Glabriusculum". Jeong et al. [120] analyzed different genotypes from Capsicum annuum L. (CLCu, CLOg and CLST), whereas Jang et al. [124] used "CM334" but different harvest times were analyzed in this study. Wahyuni et al. [84] analyzed four different species of Capsicum, Capsicum annuum, Capsicum chinense, Capsicum baccatum and Capsicum frutescens.

Besides the above mentioned dependencies, Capsicum annuum phenolic composition depends as well on several other factors, such as the ripening stage [109], cultivar [110,127], harvesting location and year [113]. For instance, Materska et al. [121] studied fruits from four different cultivars at two different maturity stages, harvested in three different years. For the eight compounds quantified in this study, the concentrations varied according to the used cultivar and maturity level. The amount of graveobioside A ranged from 160 to $1367 \mathrm{mg} / \mathrm{kg} \mathrm{dw}$. The same was true in a study from Tundis et al. [127] on two different Capsicum cultivars for the amounts of quercetin, luteolin and kaempferol. The amount of quercetin and luteolin varied between green, yellow, orange and red pepper [128]. The highest concentration of quercetin was found in yellow and green pepper fruits $(29.0-29.6 \mu \mathrm{g} / \mathrm{g} \mathrm{fw})$ while a higher amount of luteolin was reported in red pepper $(11.0 \mu \mathrm{g} / \mathrm{g} \mathrm{fw})$.

So far phenolic acids and flavonoids were identified in fruits, leaves, stems and placenta of pepper. From the phenolic acids family, hydroxybenzoic acids and hydroxycinnamic acids were reported. Other families of phenolic compounds are also present, like chalcones, stilbenes and coumarins. Nevertheless, the flavonoid class has the highest quantity of SM identified in Capsicum, as compounds belonging to the flavonol, flavan-3-ol, flavone, flavanone, flavanonol, flavanol and anthocyanidin subfamilies are reported.

Hydroxybenzoic acids are phenolic acids which have a carboxyl group substituted on a phenol. Other types of phenolic acids are the hydroxycinnamic acids. They derive from cinnamic acid, have a phenyl propane backbone and can commonly be esterified with quinic acid [42]. Phenolic acids from both subfamilies are reported in C. annuum L. fruits, leaves, stems and placenta. The major hydroxybenzoic acids present in Capsicum fruits are gallic acid (maximum reported $1013.0 \mathrm{mg} / \mathrm{kg} \mathrm{fw}$ ) and vanillic acid $(13.29 \mathrm{mg} / \mathrm{kg} \mathrm{fw})[111-113,117]$. Vanillic acid is present in Capsicum stems and placenta, and p-hydroxybenzoic acid was also detected in pepper's placenta [112]. Various hydroxycinnamic acids have been reported in pepper, namely caffeic acid, chlorogenic acid, p-coumaric acid, ferulic acid, syringic acid, sinapic acid and cinnamic as well as derivatives from the mentioned acids. Caffeic acid was identified in the placenta of C. annuum [112], 5-O-Caffeoylquinic acid is also present in the leaves [114] and chlorogenic and p-coumaric acids were identified in both stems and placenta [112]. Interestingly, 5-O-caffeoylquinic acid methyl ester and 5-O-caffeoylquinic acid butyl ester where only reported in leaves [114].

Coumarins are lactones of hydroxycinnamic acid that have a C6-C3 structure [42]. In Capsicum fruits, only four coumarins have been identified to date. Daphnetine and umbelliferone, two hydroxycoumarins, are present in high amounts of 16.29 and $14.61 \mathrm{mg} / \mathrm{kg}$ fw respectively [113,118].

Flavonols are perhaps one of the major flavonoid subfamilies present in peppers. They are structurally similar to flavones, with an additional hydroxyl group present on carbon 3 of ring C. Quercetin and its derivatives are the major flavonols present in Capsicum, with quercetin $(783.83 \mathrm{mg} / \mathrm{kg} \mathrm{fw})[107,109,113,117,118,123]$ and quercitrin $(1501.8 \mathrm{mg} / \mathrm{kg} \mathrm{fw})[108,117,118,120]$ occurring 
in high contents. Other flavonols like kaempferol and its glycosides were also reported with $1.3-160 \mathrm{mg} / \mathrm{kg} \mathrm{fw}$. Once again most of the flavonols were identified only in fruits. Nevertheless, quercetin was also identified in leaves, stems and placenta of $C$. annuum [112]. In the case of this flavonol, placenta presented the highest content with 10,270 mg/kg dw. Kaempferol is also present in the stems of Capsicum in a higher quantity than in fruits. Finally, myricetin was as well present in the placenta of C. annuum (1380 $\mathrm{mg} / \mathrm{kg} \mathrm{dw})$ [112].

Flavan-3-ols have a completely saturated ring $C$ and a hydroxyl group at the third carbon. In Capsicum, only 2 flavan-3-ols have been reported, catechin, in both stems $(30 \mathrm{mg} / \mathrm{kg} \mathrm{dw})$ and fruits $(1.1-36.8 \mathrm{mg} / \mathrm{kg} \mathrm{fw})$ and epicatechin only in fruits $(1-79.3 \mathrm{mg} / \mathrm{kg} \mathrm{fw})[111,112]$.

Flavones are also a major flavonoid subfamily present in pepper, and are characterized by having a ketone group and an unsaturated bond between the second and third carbon of the $\mathrm{C}$ ring. Luteolin-O-(apiosylmalonyl)glucoside (206.6 mg/kg fw) [120], luteolin-O-maloylpentosyldihexoside $(105.3 \mathrm{mg} / \mathrm{kg} \mathrm{fw})[120]$ and luteolin in its aglycone form $(103.5 \mathrm{mg} / \mathrm{kg} \mathrm{fw})[107,109,111,113,118,123]$ are the major flavones present in the fruits of Capsicum. In the leaves, the amount of graveobioside A is even higher than in the fruits (reaching $121.36 \mathrm{mg} / \mathrm{kg} \mathrm{fw}$ ) [114,115,121], cynaroside, another glycoside of luteolin also exist in considerable amounts in the leaves $(370 \mathrm{mg} / \mathrm{kg} \mathrm{fw})[113,114]$. However, the main flavone present in pepper leaves is apigenin-7-O- $\beta$-D-apiofuranosyl-( $1 \rightarrow 2)-\beta$-D-glucopyranoside reaching up to $3530 \mathrm{mg} / \mathrm{kg}$ fw [109].

Only two isoflavones have been identified (but not quantified) to date in Capsicum fruits, namely genistein-4,7'-dimethyl ether and 6'-O-acetyl-daidzin [116].

Flavanones are structurally very similar to flavones, with the exception of an absent double bound between second and third carbon of ring C. Only four flavanones have been identified in C. annuиm fruits, with all being derivatives of naringenin. Naringenin has been the only flavanone quantified, ranging from 1.12 to $4.46 \mathrm{mg} / \mathrm{kg} \mathrm{fw}$ [113].

One flavanonol has been identified but not quantified in Capsicum annuum, 7-O- $\beta$-Dglucopyranosyl-dihydroquercetin-3-O- $\alpha$-D-glucopyranoside, a diglucoside of taxifolin [110]. Structurally similar to flavanones, they are characterized by having a hydroxyl group linked to the third carbon of ring C.

Finally, anthocyanidins are characterized by having the ring $C$ in the form of a pyrilium kation and are typically found as glycones (linked to a sugar moiety) forming structures known as anthocyanins. In $C$. annuum fruits the anthocyanin content is mainly constituted by delphinidin derivatives. The most abundant anthocyanin is nasunin (delphinidin-3-(p-coumaroylrutinoside)-5-glucoside), being present in purple pepper fruits $(14.7-286.2 \mathrm{mg} / \mathrm{kg} \mathrm{fw})$ [125]. The content of this anthocyanin in the leaves of C. annuum is much higher $(1525 \mathrm{mg} / \mathrm{kg} \mathrm{fw})[125,126]$. Another anthocyanin, delphinidin-3-[4-(trans-coumaroyl)-L-rhamnosyl-(1 $\rightarrow 6)$-glucopyranoside]-5-O-gluco pyranoside, was reported only in the leaves of Capsicum, in an amount of $860 \mathrm{mg} / \mathrm{kg} \mathrm{fw}$ [114]; Ichiyanagi et al. [129] also reported this compound as an trans-isomer of nasunin.

Stilbenes belong to the phenolic compound family and share partially the same biosynthetic pathway as flavonoids. They have a C6-C2-C6 backbone and the general structure of two benzene rings linked together by an ethene bridge. Only one stilbene has been identified in C. annuum L. fruits, resveratrol, whose amount ranges from $3.8-12.2 \mathrm{mg} / \mathrm{kg} \mathrm{fw}$ [111].

Other phenolics compounds that have also been reported but not further quantified in Capsicum, are 2'-O- $\beta$-apiofuranosyl-arbutin, a glycosylated hydroquinone, and lariciresinol-glucopyranoside a glycosylated lignin [110]. Vanillin and conyferyl aldehyde, two phenolic aldehydes, have also been quantified in the fruits, although in small amounts $(0.19-0.85$ and $0.26-0.43 \mathrm{mg} / \mathrm{kg}$ fw respectively) [113].

As described previously and illustrated in Table 2, most studies on the phenolic composition of pepper have had a strong focus on the fruits. To date, only Chen et al. [112] reported the chemical compositions in leaves, stems and placenta of $C$. annuum. The leaves alone have been studied only by Kim et al. [114], Kashiwagi et al. [115] and Lightbourn et al. [126], with the number of compounds identified being far less than the ones found in fruits $[114,115,126]$. Nevertheless, these studies give us 
important information regarding the distribution of phenolic compounds in C. annuum, and how it can vary according to the analyzed tissue. For example, in the study of Chen et al. [112], one can see that vanillic acid was only identified in stems and placenta of $C$. annuum and not in fruits or leaves; luteolin was also present in higher amounts in stems and placenta; catechin was only identified in stems in this study, and chlorogenic acid, quercetin and kaempferol were present in higher concentration in stems comparing to the fruits. In the study of Kim et al. [114], a series of flavonoids were either only present in leaves (as it is the case of 5-O-caffeoylquinic-acid-methyl-ester, 5-O-caffeoylquinic-acid-butyl-ester, nasunin and apigenin-7-O- $\beta$-D-apio-furanosyl-( $1 \rightarrow 2)-\beta$-D-glucopyranoside) or were present with higher quantities in leaves than in fruits (the case of 5-O-caffeoylquinic-acid, graveobioside $\mathrm{A}$ and cynaroside). Lightbourn et al. [126] also identified nasunin in pepper fruits, but once again concluded that the amount of this anthocyanidin was much higher in leaves.

These studies reflect that SM, namely flavonoids, are differently distributed in the pepper plant. Some of these metabolites exist in higher concentrations in other tissues of the crop than fruits. Further studies regarding the phenolic composition of different Capsicum plant tissues are needed in order to elucidate the distribution of SM in the plant.

\section{Possible Strategies to Increase Phenolic Compounds in Capsicum annuum}

There is compelling evidence that plant SM and especially flavonoids are beneficial for human health, which led to dietary recommendations for consumption of fruits and vegetables rich in bio-active compounds in recent years [1-3]. As these recommendation campaigns have been relatively unsuccessful so far, the idea of producing foods and food supplements with enhanced concentrations of SM to support human health and decrease micronutrient deficiency is worth considering, although no precise levels of SM concentrations can be recommended due to several factors [130]. Furthermore, increased levels of SM in residual biomass could be valuable for extraction purposes and usage for industrial applications.

Capsicum is a crop of major agricultural and economic importance and has been domesticated for several thousand years [131]. Early breeding approaches have focused on variety improvement regarding fruit size, shape and color, as well as non-pungency (bell-type peppers are commercially most important). Accordingly, many of the identified QTLs are related to these traits [132]. High-yield in combination with resistance to pests and diseases and protection against abiotic stress are strong selection criteria for breeding strategies. In addition, improvement of fruit quality for consumption (taste, smell, color and appearance to consumer) or usage in industry (processing, pungency) is also in the focus of breeders. Years of domestication of pepper, however, have led to loss of genetic diversity, leading to higher susceptibility to diseases and stress [82].

Several studies showed that peppers contain relevant amounts of beneficial phytochemicals, such as vitamins, capsaicinoids and phenolic compounds [40]. This in combination with the increasing consumption worldwide makes Capsicum an interesting target to improve the production of SM, especially flavonoids. As discussed above (chapter 3), the content and composition of phenolic compounds in fruits, and concomitantly the antioxidant activity, varies between different accessions. Therefore, a possible strategy to enhance the concentrations of beneficial SM could be the selection for cultivars with already high amounts of flavonoids for hybridization-based breeding [40]. In addition, wild Capsicum germplasm could be used for breeding, as it has been shown that non-domesticated species often contain higher levels of polyphenolics than cultivated varieties [133,134]. In general, broader studies looking into the flavonoid contents and phenolics composition of many different cultivated pepper accessions and wild species are necessary to provide a good foundation for targeted breeding approaches. Although generating a cultivar with the desirable trait (e.g., increased flavonoid content) without losing any other usual breeding criteria takes a long time, breeding programs have a large potential in generating cultivars with enhanced concentrations of phenolic compounds, as shown for cranberry, strawberry, peach and plum [135-137]. 
Our current knowledge about flavonoid pathways, their genes and regulation, as outlined above, provides the basis for metabolic engineering as a measure to increase flavonoid content, although further studies are necessary to pinpoint structural and regulatory genes of the respective biosynthesis pathways in pepper, as well as developmental and tissue-specific regulation.

Manipulation of secondary metabolism by genetic engineering has been proven successful in several plants, among others tomato, via several strategies: On the one hand, overexpression of structural genes of flavonoid pathways from different plant sources (e.g., Petunia hybrida, Vitis vinifera) in tomato was successfully used to overcome rate-limiting steps of the respective biosynthesis pathways leading to flavonoid accumulation or even producing new flavonoids [138-140]. In addition, downregulation of key genes of the lignin biosynthesis pathway in tomato (lignin shares common precursors with phenolic compounds) resulted in metabolic flux being redirected into the production of other phenolic compounds (e.g., chlorogenic acid, rutin) [141]. Another approach involves genetic manipulation of regulatory genes like TFs. Fruit-specific expression of maize TF genes in tomato led to an upregulation of the flavonoid pathway and high levels of kaempferol and naringenin were detected [142]. Similarly, two TFs from Antirrhinum majus caused accumulation of anthocyanin in tomato fruits, with concentrations being even comparable to those found in blackberries and blueberries [143]. The combination of several TFs expressed in tomato fruits did not only caused induction of the flavonoid biosynthesis pathway but even altered carbon flux and increased the supply from carbon metabolism [65].

The technical potential of metabolic engineering on pepper appears very promising, as shown by the few examples of successful manipulation of anthocyanin biosynthesis $[77,81]$. However, the commercialization of genetically modified pepper fruits, at least in Europe, might represent difficult. European consumers most likely will not accept genetically engineered plant products and even the relatively new, precise gene-editing technologies such as CRISPR-Cas9 have just been declared to fall under the same stringent regulations as do conventional genetically modified organisms.

A further approach to improve fruit quality of peppers, without time-consuming breeding or controversial genetic modifications, could be adjustment of environmental conditions during cultivation. It is known that plant SM are induced significantly in response to biotic or abiotic stress [144-146] and this has been reviewed in detail elsewhere [147]. Application of stress with the aim to improve product quality has mainly been investigated for medicinal plants (reviewed in reference [148]) but several studies about the effect of stress treatments on vegetables and fruits have also been performed [149-155]. Regarding phenolic compounds and flavonoids, an increase of up to $150 \%$ of lutein was found in broccoli under low temperature [150], whereas certain cultivars of strawberry would even increase anthocyanins up to $240 \%$ [151]. Light intensity during cultivation was also shown to affect polyphenols positively in apple [152] and tomato [153,154] even after harvest [155].

However, information regarding stress-effects on polyphenols in Capsicum is scarce. One study reported no or even negative effects of salt on phenolic compounds which were dependent on intensity of salinity and the maturity stage of the pepper fruit [156]. In contrast, positive effects of high salt concentrations on SM levels were observed in tomato and strawberry [157-159]. Furthermore, different cultivation conditions affected the accumulation of antioxidants in different sweet pepper cultivars [160]. Organic farming reduced the total phenolics content in both ripe and unripe fruits in twenty-five pepper accessions compared to conventional cultivation, whereas seven accessions showed induction effects under organic farming [161]. This shows that the choice of environment and pepper variety can enhance individual antioxidant potential of fruits to improve health benefits for consumers.

Elicitors are often used to encourage the production of SM such as flavonoids, terpenoids or alkaloids in plants [162,163]. Examples for potent elicitors include phytohormones such as jasmonate or salicylic acid (SA) and substances of microbial origin such as chitosan [164]. Jasmonates and in particular methyl jasmonate (MeJA) play a central role in biosynthesis of nearly all SM, e.g., flavonoids and alkaloids [165], and it has been reported that MeJA can induce production of phenolics and flavonoids in bell pepper and Arabidopsis [166,167]. In addition, foliar application of SA and chitosan 
significantly increased the activity of PAL, the key enzyme of phenylpropanoid metabolism, which could suggest accumulation of phenolic compounds as a result [168].

The approach to selectively trigger the production of flavonoids or phenolic compounds in pepper fruits by controlled environmental stresses seems promising but requires further investigation. This includes more in-depth studies on Capsicum phenolic composition regarding the effect of different cultivation/stress conditions, stress intensity and duration. Also genotype $x$ environment interactions need to be further investigated in order to identify suitable cultivar-stress/elicitor combinations with a large potential for induction of SM. A challenge will be to identify stress treatments that increase the levels of phenolic compounds in pepper fruits without causing any yield loss and are easily transferable and applicable in horticultural practices. A study in tomato showed that nitrogen and general mineral limitation applied in a commercial like greenhouse increased the concentrations of rutin and solanesol in leaves [169], however, stressed plants more frequently showed symptoms of blossom end rot on fruits.

Environmental stress will not only affect SM levels in pepper fruits but also affect the whole plant. Annual pepper cultivation produces considerable amounts of green biomass $\left(1.3 \mathrm{~kg} \mathrm{~m}^{-2}\right.$ per season) [170]. This biomass is currently underutilized as it is usually composted or used for combustion, although high amounts of SM and antioxidant activity has also been found, for example in pepper stalks [112]. Therefore, side streams of horticultural production could be used in combination with stress applications to extract SM for industrial purposes, which would enhance the resource efficiency of this food production system and will add an enormous value to this crop [171]. To circumvent any negative effects on fruit yield, stress treatments could be performed at the end of fruit production, targeting only the residual biomass. This bio-economic concept would represent an expansion of the current, horticultural value chain towards a cascade utilization of pepper biomass.

However, as outlined above, little is known about the composition of phenolic compounds in leaves and stems of peppers or their inducibility by stress, therefore these tissues need to be included in future experimental designs analyzing stress responses of peppers. A recent interdisciplinary study with tomato identified the key aspects for the valorization of tomato residual biomass by extraction of SM. These are the effective induction of SM content in leaves, but also the feasibility of stress applications in horticultural practice, economic factors (market value of SM versus additional cost for treatment, extraction, logistics) as well as socio-economic aspects like acceptance from the value-chain actor and consumer side ([171], and L. Junker personal communication).

The recent developments and studies investigating the secondary metabolism not only in fruits but also other plant tissues increased our understanding and showed the total potential of pepper plants. Nevertheless, our limited actual knowledge of the biosynthesis and distribution of phenolic compounds and in particular flavonoids in tissues other than fruits should be further investigated to develop targeted approaches for metabolic engineering, and/or tailoring cascades in horticulture. In addition, this implies the conceptualization of multi-disciplinary projects to cover the entire value-chain in horticulture, while also including socio-economic effects. As a first step a changed focus from anthocyanidins (as coloring agents) to other flavonoids would be preferable, as parts of these pathways are already well studied in pepper. In summary, peppers are a great resource of metabolites with protective impacts for the plant, and for coloring and flavoring our daily life.

Author Contributions: Conceptualization, A.W.; Writing-Original Draft Preparation, V.C.L., J.J.R., A.W.; Writing-Review \& Editing, V.C.L., J.J.R., A.W.; Visualization, V.C.L., J.J.R., A.W.; Funding Acquisition, J.J.R., A.W.

Funding: This research was supported by the German Federal Ministry of Education and Research (grant number: 031B0361A) as well as the Ministry of Innovation, Science and Research of North-Rhine Westphalia within the framework of the North-Rhine Westphalia Strategieprojekt BioEconomy Science Center (grant number 313/323-400-00213).

Acknowledgments: We would like to thank Björn Usadel for critical reading and commenting of the manuscript.

Conflicts of Interest: The authors declare no conflict of interest 


\section{References}

1. World Health Organisation (WHO). Available online: https://www.who.int/news-room/fact-sheets/detail/ healthy-diet (accessed on 29 March 2019).

2. 2015-2020 Dietary Guidelines. Available online: https://health.gov/dietaryguidelines/2015/guidelines/ (accessed on 29 March 2019).

3. Food and Agriculture Organization of the United Nations | Food-Based Dietary Guidelines. Available online: http://www.fao.org/nutrition/education/food-dietary-guidelines/regions/europe/en/ (accessed on 29 March 2019).

4. Wu, S.; Chappell, J. Metabolic engineering of natural products in plants; tools of the trade and challenges for the future. Curr. Opin. Biotechnol. 2008, 19, 145-152. [CrossRef] [PubMed]

5. Wink, M. Evolution of secondary metabolites from an ecological and molecular phylogenetic perspective. Phytochemistry 2003, 64, 3-19. [CrossRef]

6. Li, J.; Ou-Lee, T.M.; Raba, R.; Amundson, R.G.; Last, R.L. Arabidopsis flavonoid mutants are hypersensitive to UV-B irradiation. Plant Cell 1993, 5, 171-179. [CrossRef]

7. Bennett, R.N.; Wallsgrove, R.M. Secondary metabolites in plant defense mechanisms. New Phytol. 1994, 127, 617-633. [CrossRef]

8. Wink, M. Importance of plant secondary metabolites for protection against insects and microbial infections. Adv. Phytomed. 2006, 3, 251-268. [CrossRef]

9. Wittstock, U.; Gershenzon, J. Constitutive plant toxins and their role in defense against herbivores and pathogens. Curr. Opin. Plant Biol. 2002, 5, 300-307. [CrossRef]

10. López-Goldar, X.; Villari, C.; Bonello, P.; Borg-Karlson, A.K.; Grivet, D.; Zas, R.; Sampedro, L. Inducibility of plant secondary metabolites in the stem predicts genetic variation in resistance against a key insect herbivore in maritime pine. Front. Plant Sci. 2018, 9, 1651. [CrossRef]

11. Schreiner, M.; Mewis, I.; Huyskens-Keil, S.; Jansen, M.A.K.; Zrenner, R.; Winkler, J.B.; O’Brien, N.; Krumbein, A. UV-B-induced secondary plant metabolites - Potential benefits for plant and human health. CRC. Crit. Rev. Plant Sci. 2012, 31, 229-240. [CrossRef]

12. Tohge, T.; Wendenburg, R.; Ishihara, H.; Nakabayashi, R.; Watanabe, M.; Sulpice, R.; Hoefgen, R.; Takayama, H.; Saito, K.; Stitt, M.; et al. Characterization of a recently evolved flavonol-phenylacyltransferase gene provides signatures of natural light selection in Brassicaceae. Nat. Commun. 2016, 7, 12399. [CrossRef]

13. Stevenson, P.C.; Nicolson, S.W.; Wright, G.A. Plant secondary metabolites in nectar: Impacts on pollinators and ecological functions. Funct. Ecol. 2017, 31, 65-75. [CrossRef]

14. Harborne, J.B. Secondary Metabolites: Attracting Pollinators. In Encyclopedia of Life Sciences; John Wiley \& Sons, Ltd.: Chichester, UK, 2011. [CrossRef]

15. Wink, M. Plant secondary metabolites modulate insect behavior-steps toward addiction? Front. Physiol. 2018, 9, 364. [CrossRef]

16. Crozier, A.; Clifford, M.N.; Ashihara, H. Plant Secondary Metabolites: Occurrence, Structure and Role in the Human Diet; Blackwell: Oxford, UK, 2006; ISBN 9780470988558.

17. Fernandes, I.; Pérez-Gregorio, R.; Soares, S.; Mateus, N.; de Freitas, V.; Fernandes, I.; Pérez-Gregorio, R.; Soares, S.; Mateus, N.; De Freitas, V. Wine flavonoids in health and disease prevention. Molecules 2017, 22, 292. [CrossRef] [PubMed]

18. Silva-Beltrán, N.P.; Ruiz-Cruz, S.; Chaidez, C.; Ornelas-Paz, J.d.J.; López-Mata, M.A.; Márquez-Ríos, E.; Estrada, M.I. Chemical constitution and effect of extracts of tomato plants byproducts on the enteric viral surrogates. Int. J. Environ. Health Res. 2015, 25, 299-311. [CrossRef]

19. Taveira, M.; Silva, L.R.; Vale-Silva, L.A.; Pinto, E.; Valentão, P.; Ferreres, F.; Guedes de Pinho, P.; Andrade, P.B. Lycopersicon esculentum seeds: An industrial byproduct as an antimicrobial agent. J. Agric. Food Chem. 2010, 58, 9529-9536. [CrossRef] [PubMed]

20. Van Hung, P. Phenolic compounds of cereals and their antioxidant capacity. Crit. Rev. Food Sci. Nutr. 2016, 56, 25-35. [CrossRef] [PubMed]

21. Imran, M.; Rauf, A.; Shah, Z.A.; Saeed, F.; Imran, A.; Arshad, M.U.; Ahmad, B.; Bawazeer, S.; Atif, M.; Peters, D.G.; et al. Chemo-preventive and therapeutic effect of the dietary flavonoid kaempferol: A comprehensive review. Phyther. Res. 2019, 33, 263-275. [CrossRef] [PubMed] 
22. Salehi, B.; Venditti, A.; Sharifi-Rad, M.; Kręgiel, D.; Sharifi-Rad, J.; Durazzo, A.; Lucarini, M.; Santini, A.; Souto, E.; Novellino, E.; et al. The therapeutic potential of apigenin. Int. J. Mol. Sci. 2019, 20, 1305. [CrossRef]

23. Salehi, B.; Fokou, P.; Sharifi-Rad, M.; Zucca, P.; Pezzani, R.; Martins, N.; Sharifi-Rad, J.; Salehi, B.; Fokou, P.V.T.; Sharifi-Rad, M.; et al. The therapeutic potential of naringenin: A review of clinical trials. Pharmaceuticals 2019, 12, 11. [CrossRef] [PubMed]

24. Ginwala, R.; Bhavsar, R.; Chigbu, D.I.; Jain, P.; Khan, Z.K. Potential role of flavonoids in treating chronic inflammatory diseases with a special focus on the anti-inflammatory activity of apigenin. Antioxidants 2019, 8, 35. [CrossRef] [PubMed]

25. Serino, A.; Salazar, G.; Serino, A.; Salazar, G. Protective role of polyphenols against vascular inflammation, aging and cardiovascular disease. Nutrients 2018, 11, 53. [CrossRef]

26. Krga, I.; Milenkovic, D. Anthocyanins: From sources and bioavailability to cardiovascular-health benefits and molecular mechanisms of action. J. Agric. Food Chem. 2019, 67, 1771-1783. [CrossRef] [PubMed]

27. Li, R.; Zhang, Y.; Rasool, S.; Geetha, T.; Babu, J.R. Effects and underlying mechanisms of bioactive compounds on type 2 diabetes mellitus and Alzheimer's disease. Oxid. Med. Cell. Longev. 2019, 2019, 1-25. [CrossRef]

28. Zhou, Y.; Zheng, J.; Li, Y.; Xu, D.-P.; Li, S.; Chen, Y.-M.; Li, H.-B. Natural polyphenols for prevention and treatment of cancer. Nutrients 2016, 8, 515. [CrossRef] [PubMed]

29. Caltagirone, S.; Rossi, C.; Poggi, A.; Ranelletti, F.O.; Natali, P.G.; Brunetti, M.; Aiello, F.B.; Piantelli, M. Flavonoids apigenin and quercetin inhibit melanoma growth and metastatic potential. Int. J. Cancer 2000, 87, 595-600. [CrossRef]

30. Oksman-Caldentey, K.M.; Inzé, D. Plant cell factories in the post-genomic era: New ways to produce designer secondary metabolites. Trends Plant Sci. 2004, 9, 433-440. [CrossRef] [PubMed]

31. McChesney, J.D.; Venkataraman, S.K.; Henri, J.T. Plant natural products: Back to the future or into extinction? Phytochemistry 2007, 68, 2015-2022. [CrossRef] [PubMed]

32. Farhoudi, R.; Mehrnia, M.A.; Lee, D.-J. Antioxidant activities and bioactive compounds of five Jalopeno peppers (Capsicum annuum) cultivars. Nat. Prod. Res. 2017. [CrossRef]

33. Bosland, P.W.; Votava, E.J. Peppers: Vegetable and Spice Capsicums; CABI: Oxfordshire, UK, 2012; ISBN 178064020X.

34. Wahyuni, Y.; Ballester, A.-R.; Sudarmonowati, E.; Bino, R.J.; Bovy, A.G. Secondary metabolites of Capsicum species and their importance in the human diet. J. Nat. Prod. 2013, 76, 783-793. [CrossRef]

35. FAOSTAT. Available online: http://faostat3.fao.org/home/E (accessed on 13 March 2015).

36. Salvatore, S.; Pellegrini, N.; Serafini, M.; Del Rio, D.; Brighenti, F.; Bianchi, M.; Colombi, B. Total antioxidant capacity of plant foods, beverages and oils consumed in Italy assessed by three different in vitro assays. J. Nutr. 2018, 133, 2812-2819. [CrossRef]

37. Zimmer, A.R.; Leonardi, B.; Miron, D.; Schapoval, E.; Oliveira, J.R. De Gosmann, G. Antioxidant and anti-inflammatory properties of Capsicum baccatum: From traditional use to scientific approach. J. Ethnopharmacol. 2012, 139, 228-233. [CrossRef]

38. Morales-Soto, A.; García-Salas, P.; Rodríguez-Pérez, C.; Jiménez-Sánchez, C.; de la Luz Cádiz-Gurrea, M.; Segura-Carretero, A.; Fernández-Gutiérrez, A. Antioxidant capacity of 44 cultivars of fruits and vegetables grown in Andalusia (Spain). Food Res. Int. 2014, 58, 35-46. [CrossRef]

39. Olatunji, T.L.; Afolayan, A.J. The suitability of chili pepper (Capsicum annuum L.) for alleviating human micronutrient dietary deficiencies: A review. Food Sci. Nutr. 2018, 6, 2239-2251. [CrossRef] [PubMed]

40. Kantar, M.B.; Anderson, J.E.; Lucht, S.A.; Mercer, K.; Bernau, V.; Case, K.A.; Le, N.C.; Frederiksen, M.K.; DeKeyser, H.C.; Wong, Z.-Z.; et al. Vitamin variation in Capsicum spp. provides opportunities to improve nutritional value of human diets. PLOS ONE 2016, 11, e0161464. [CrossRef] [PubMed]

41. Barros, J.; Serrani-Yarce, J.C.; Chen, F.; Baxter, D.; Venables, B.J.; Dixon, R.A. Role of bifunctional ammonia-lyase in grass cell wall biosynthesis. Nat. Plants 2016, 2, 16050. [CrossRef] [PubMed]

42. Vermerris, W.; Nicholson, R. Phenolic Compound Biochemistry; Springer: Berlin, Germany, 2008; ISBN 978-1-4020-5163-0.

43. Vukics, V.; Guttman, A. Structural characterization of flavonoid glycosides by multi-stage mass spectrometry. Mass Spectrom. Rev. 2010, 29, 1-16. [CrossRef] [PubMed]

44. Belitz, H.D.; Grosch, W.; Schieberle, P. Food Chemistry; Springer-Verlag: Berlin/Heidelberg, Germany, 2009; ISBN 9783540699330.

45. Dewick, P.M. The shikimic pathway: Aromatic aminoacids and phenylpropanoids. In Medicinal Natural Products: A Biosynthetic Approach; John Wiley \& Sons, Ltd.: Hoboken, NJ, USA, 2012; ISBN 9780470741689. 
46. Nishiumi, S.; Miyamoto, S.; Kawabata, K.; Ohnishi, K.; Mukai, R.; Murakami, A.; Ashida, H.; Terao, J. Dietary flavonoids as cancer-preventive and therapeutic biofactors. Front. Biosci. 2011, 3, 1332-1362. [CrossRef]

47. Santos, E.L.; Maia, B.H.L.N.S.; Ferriani, A.P.; Teixeira, S.D. Flavonoids: Classification, Biosynthesis and Chemical Ecology. In Flavonoids_From Biosynthesis to Human Health; IntechOpen Limited: London, UK, 2017; ISBN 978-953-51-3424-4.

48. Hui, Y.H.; Nip, W.K.; Nollet, L.M.L.; Paliyath, G.; Simpson, B.K. Food Biochemistry and Food Processing; Blackwell: Oxford, UK, 2007; ISBN 0813803780.

49. Dewick, P.M. Medicinal Natural Products. A Biosynthetic Approach, 2nd ed.; John Wiley \& Sons, Ltd.: Hoboken, NJ, USA, 2002; ISBN 9780470846278.

50. Andersen, O.M.; Markham, K.R. Flavonoids. Chemistry, Biochemistry and Applications; CRC Press: Boca Raton, FL, USA, 2006; ISBN 0-8493-2021-6.

51. Maeda, H.; Dudareva, N. The shikimate pathway and aromatic amino acid biosynthesis in plants. Annu. Rev. Plant Biol. 2012, 63, 73-105. [CrossRef]

52. Bomati, E.K.; Austin, M.B.; Bowman, M.E.; Dixon, R.A.; Noel, J.P. Structural elucidation of chalcone reductase and implications for deoxychalcone biosynthesis. J. Biol. Chem. 2005, 280, 30496-30503. [CrossRef] [PubMed]

53. Saito, K.; Yonekura-Sakakibara, K.; Nakabayashi, R.; Higashi, Y.; Yamazaki, M.; Tohge, T.; Fernie, A.R. The flavonoid biosynthetic pathway in Arabidopsis: Structural and genetic diversity. Plant Physiol. Biochem. 2013, 72, 21-34. [CrossRef] [PubMed]

54. Dixon, R.A.; Xie, D.-Y.; Sharma, S.B. Proanthocyanidins-A final frontier in flavonoid research? New Phytol. 2004, 165, 9-28. [CrossRef]

55. Abrahams, S.; Lee, E.; Walker, A.R.; Tanner, G.J.; Larkin, P.J.; Ashton, A.R. The Arabidopsis TDS4 gene encodes leucoanthocyanidin dioxygenase (LDOX) and is essential for proanthocyanidin synthesis and vacuole development. Plant J. 2003, 35, 624-636. [CrossRef]

56. Austin, M.B.; Noel, J.P. The chalcone synthase superfamily of type III polyketide synthases. Nat. Prod. Rep. 2003, 20, 79-110. [CrossRef]

57. Winkel-Shirley, B. Flavonoid Biosynthesis. A colorful model for genetics, biochemistry, cell biology, and biotechnology. Plant Physiol. 2002, 126, 485-493. [CrossRef]

58. Turnbull, J.J.; Nakajima, J.I.; Welford, R.W.D.; Yamazaki, M.; Saito, K.; Schofield, C.J. Mechanistic studies on three 2-oxoglutarate-dependent oxygenases of flavonoid biosynthesis: Anthocyanidin synthase, flavonol synthase, and flavanone 3ß-hydroxylase. J. Biol. Chem. 2004, 279, 1206-1216. [CrossRef] [PubMed]

59. Schoenbohm, C.; Martens, S.; Eder, C.; Forkmann, G.; Weisshaar, B. Identification of the Arabidopsis thaliana flavonoid 3'-hydroxylase gene and functional expression of the encoded P450 enzyme. Biol. Chem. 2000, 381, 749-753. [CrossRef] [PubMed]

60. Cone, K.C.; Burr, F.A.; Burr, B. Molecular analysis of the maize anthocyanin regulatory locus C1. Proc. Natl. Acad. Sci. USA 1986, 83, 9631-9635. [CrossRef] [PubMed]

61. Larson, R.; Bussard, J.B.; Coe, E.H. Gene-dependent flavonoid 3'-hydroxylation in maize. Biochem. Genet. 1986, 24, 615-624. [CrossRef] [PubMed]

62. O'Neill, S.D.; Tong, Y.; Spörlein, B.; Forkmann, G.; Yoder, J.I. Molecular genetic analysis of chalcone synthase in Lycopersicon esculentum and an anthocyanin-deficient mutant. Mol. Gen. Genet. 1990, 224, 279-288. [CrossRef]

63. Kang, J.-H.; Mcroberts, J.; Shi, F.; Moreno, J.E.; Jones, A.D.; Howe, G.A. The flavonoid biosynthetic enzyme chalcone isomerase modulates terpenoid production in glandular trichomes of tomato. Plant Physiol. 2014, 164, 1161-1174. [CrossRef]

64. Tohge, T.; Zhang, Y.; Peterek, S.; Matros, A.; Rallapalli, G.; Tandrõn, Y.A.; Butelli, E.; Kallam, K.; Hertkorn, N.; Mock, H.P.; et al. Ectopic expression of snapdragon transcription factors facilitates the identification of genes encoding enzymes of anthocyanin decoration in tomato. Plant J. 2015, 83, 686-704. [CrossRef]

65. Zhang, Y.; Butelli, E.; Alseekh, S.; Tohge, T.; Rallapalli, G.; Luo, J.; Kawar, P.G.; Hill, L.; Santino, A.; Fernie, A.R.; et al. Multi-level engineering facilitates the production of phenylpropanoid compounds in tomato. Nat. Commun. 2015, 26, 8635. [CrossRef] [PubMed]

66. Burbulis, I.E.; Winkel-Shirley, B. Interactions among enzymes of the Arabidopsis flavonoid biosynthetic pathway. Proc. Natl. Acad. Sci. USA 2002, 96, 12929-12934. [CrossRef] 
67. Eloy, N.B.; Voorend, W.; Lan, W.; Saleme, M.D.L.S.; Cesarino, I.; Vanholme, R.; Smith, R.A.; Goeminne, G.; Pallidis, A.; Morreel, K.; et al. Silencing CHALCONE SYNTHASE in maize impedes the incorporation of tricin into lignin and increases lignin content. Plant Physiol. 2017, 173, 998-1016. [CrossRef]

68. Bongue-Bartelsman, M.; O'Neill, S.D.; Yusen, T.; Yoder, J.I. Characterization of the gene encoding dihydroflavonol 4-reductase in tomato. Gene 1994, 138, 153-157. [CrossRef]

69. Ralston, E.J.; English, J.J.; Dooner, H.K. Sequence of three bronze alleles of maize and correlation with the genetic fine structure. Genetics 1988, 119, 185-197.

70. Devic, M.; Guilleminot, J.; Debeaujon, I.; Bechtold, N.; Bensaude, E.; Koornneef, M.; Pelletier, G.; Delseny, M. The BANYULS gene encodes a DFR-like protein and is a marker of early seed coat development. Plant $J$. 1999, 19, 387-398. [CrossRef] [PubMed]

71. Lepiniec, L.; Debeaujon, I.; Routaboul, J.-M.; Baudry, A.; Pourcel, L.; Nesi, N.; Caboche, M. Genetics and biochemistry of seed flavonoids. Annu. Rev. Plant Biol. 2006, 57, 405-430. [CrossRef] [PubMed]

72. Nesi, N.; Jond, C.; Debeaujon, I.; Caboche, M.; Lepiniec, L. The Arabidopsis TT2 gene encodes an R2R3 MYB domain protein that acts as a key determinant for proanthocyanidin accumulation in developing seed. Plant Cell 2001, 13, 2099-2114. [CrossRef] [PubMed]

73. Walker, A.R.; Davison, P.A.; Bolognesi-Winfield, A.C.; James, C.M.; Srinivasan, N.; Blundell, T.L.; Esch, J.J.; Marks, M.D.; Gray, J.C. The TRANSPARENT TESTA GLABRA1 locus, which regulates trichome differentiation and anthocyanin biosynthesis in Arabidopsis, encodes a WD40 Repeat protein. Plant Cell Online 1999, 11, 1337-1350. [CrossRef]

74. Riechmann, J.L.; Heard, J.; Martin, G.; Reuber, L.; Jiang, C.; Keddie, J.; Adam, L.; Pineda, O.; Ratcliffe, O.J.; Samaha, R.R.; et al. Arabidopsis transcription factors: Genome-wide comparative analysis among eukaryotes. Science 2000, 290, 2105-2110. [CrossRef] [PubMed]

75. Eulgem, T.; Rushton, P.; Robatzek, S.; Somssich, I. The WRKY superfamily of plant transcription factors. Trends Plant Sci. 2000, 5, 199-206. [CrossRef]

76. Gonzalez, A.; Brown, M.; Hatlestad, G.; Akhavan, N.; Smith, T.; Hembd, A.; Moore, J.; Montes, D.; Mosley, T.; Resendez, J.; et al. TTG2 controls the developmental regulation of seed coat tannins in Arabidopsis by regulating vacuolar transport steps in the proanthocyanidin pathway. Dev. Biol. 2016, 419, 54-63. [CrossRef] [PubMed]

77. Aguilar-Barragán, A.; Ochoa-Alejo, N. Virus-induced silencing of MYB and WD40 transcription factor genes affects the accumulation of anthocyanins in chili pepper fruit. Biol. Plant. 2014, 58,567-574. [CrossRef]

78. Aza-González, C.; Herrera-Isidrón, L.; Núñez-Palenius, H.G.; Martínez De La Vega, O.; Ochoa-Alejo, N. Anthocyanin accumulation and expression analysis of biosynthesis-related genes during chili pepper fruit development. Biol. Plant. 2013, 57, 49-55. [CrossRef]

79. Stommel, J.R.; Lightbourn, G.J.; Winkel, B.S.; Griesbach, R.J. Transcription factor families regulate the anthocyanin biosynthetic pathway in Capsicum annuum. J. Am. Soc. Hortic. Sci. 2009, 134, 244-251. [CrossRef]

80. Li, J.-G.; Li, H.-L.; Peng, S.-Q. Three R2R3 MYB transcription factor genes from Capsicum annuum showing differential expression during fruit ripening. African J. Biotechnol. 2011, 10. [CrossRef]

81. Zhang, Z.; Li, D.-W.; Jin, J.-H.; Yin, Y.-X.; Zhang, H.-X.; Chai, W.-G.; Gong, Z.-H. VIGS approach reveals the modulation of anthocyanin biosynthetic genes by CaMYB in chili pepper leaves. Front. Plant Sci. 2015, 6, 500. [CrossRef]

82. Qin, C.; Yu, C.; Shen, Y.; Fang, X.; Chen, L.; Min, J.; Cheng, J.; Zhao, S.; Xu, M.; Luo, Y.; et al. Whole-genome sequencing of cultivated and wild peppers provides insights into Capsicum domestication and specialization. Proc. Natl. Acad. Sci. USA 2014, 111, 5135-5140. [CrossRef]

83. Kim, S.; Park, M.; Yeom, S.I.; Kim, Y.M.; Lee, J.M.; Lee, H.A.; Seo, E.; Choi, J.; Cheong, K.; Kim, K.T.; et al. Genome sequence of the hot pepper provides insights into the evolution of pungency in Capsicum species. Nat. Genet. 2014, 46, 270-278. [CrossRef] [PubMed]

84. Wahyuni, Y.; Ballester, A.-R.; Sudarmonowati, E.; Bino, R.J.; Bovy, A.G. Metabolite biodiversity in pepper (Capsicum) fruits of thirty-two diverse accessions: Variation in health-related compounds and implications for breeding. Phytochemistry 2011, 72, 1358-1370. [CrossRef]

85. Ainsworth, E.A.; Gillespie, K.M. Estimation of total phenolic content and other oxidation substrates in plant tissues using Folin-Ciocalteu reagent. Nat. Protoc. 2007, 2, 875-877. [CrossRef] [PubMed]

86. Baba, S.A.; Malik, S.A. Determination of total phenolic and flavonoid content, antimicrobial and antioxidant activity of a root extract of Arisaema jacquemontii Blume. J. Taibah Univ. Sci. 2015, 9, 449-454. [CrossRef] 
87. Noreen, H.; Semmar, N.; Farman, M.; McCullagh, J.S.O. Measurement of total phenolic content and antioxidant activity of aerial parts of medicinal plant Coronopus didymus. Asian Pac. J. Trop. Med. 2017, 10, 792-801. [CrossRef]

88. Folin, O.; Ciocalteau, V. Tyrosine and tryptophane determination in proteins. J. Biol. Chem. 1927, 73, 627-650.

89. Sánchez-Rangel, J.C.; Benavides, J.; Heredia, J.B.; Cisneros-Zevallos, L.; Jacobo-Velázquez, D.A. The Folin-Ciocalteu assay revisited: Improvement of its specificity for total phenolic content determination. Anal. Methods 2013, 5, 5990. [CrossRef]

90. Singleton, V.L.; Orthofer, R.; Lamuela-Raventós, R.M. [14] Analysis of total phenols and other oxidation substrates and antioxidants by means of folin-ciocalteu reagent. Methods Enzymol. 1999, 299, 152-178. [CrossRef]

91. Contreras Guzman, E.S.; Strong F., C. Determination of tocopherols (vitamin e) by reduction of cupric ion. J. Assoc. Off. Anal. Chem. 1982, 65, 1215-1221.

92. Sánchez-Moreno, C.; Larrauri, J.A.; Saura-Calixto, F. A procedure to measure the antiradical efficiency of polyphenols. J. Sci. Food Agric. 1998, 76. [CrossRef]

93. Stratil, P.; Klejdus, B.; Kubán̆, V. Determination of total content of phenolic compounds and their antioxidant activity in vegetables-Evaluation of spectrophotometric methods. J. Agric. Food Chem. 2006, 54, 607-616. [CrossRef]

94. Bondet, V.; Brand-Williams, W.; Berset, C. Kinetics and mechanisms of antioxidant activity using the DPPH• free radical method. LWT Food Sci. Technol. 1997, 30, 609-615. [CrossRef]

95. Butkovic, V.; Klasinc, L.; Bors, W. Kinetic study of flavonoid reactions with stable radicals. J. Agric. Food Chem. 2004, 52, 2816-2820. [CrossRef]

96. Kim, D.O.; Lee, K.W.; Lee, H.J.; Lee, C.Y. Vitamin C equivalent antioxidant capacity (VCEAC) of phenolic phytochemicals. J. Agric. Food Chem. 2002, 50, 3713-3717. [CrossRef]

97. Awika, J.M.; Rooney, L.W.; Wu, X.; Prior, R.L.; Cisneros-Zevallos, L. Screening methods to measure antioxidant activity of orghum (Sorghum bicolor) and Sorghum products. J. Agric. Food Chem. 2003, 51, 6657-6662. [CrossRef]

98. Mishra, K.; Ojha, H.; Chaudhury, N.K. Estimation of antiradical properties of antioxidants using DPPHassay: A critical review and results. Food Chem. 2012, 130, 1036-1043. [CrossRef]

99. Papariello, G.J.; Janish, M.A.M. Diphenylpicrylhydrazyl as an Organic Analytical Reagent in the Spectrophotometric Analysis of Phenols. Anal. Chem. 1966, 38, 211-214. [CrossRef]

100. Dawidowicz, A.L.; Wianowska, D.; Olszowy, M. On practical problems in estimation of antioxidant activity of compounds by DPPH method (Problems in estimation of antioxidant activity). Food Chem. 2012, 131, 1037-1043. [CrossRef]

101. McGowan, J.C.; Powell, T.; Raw, R. The rates of reaction of $\alpha \alpha$-diphenyl- $\beta$-picrylhydrazyl with certain amines and phenols. J. Chem. Soc. 1959, 630, 3103-3110. [CrossRef]

102. Xie, J.; Schaich, K.M. Re-evaluation of the 2,2-diphenyl-1-picrylhydrazyl free radical (DPPH) assay for antioxidant activity. J. Agric. Food Chem. 2014, 62, 4251-4260. [CrossRef]

103. Re, R.; Pellegrini, N.; Proteggente, A.; Pannala, A.; Yang, M.; Rice-Evans, C. Antioxidant activity applying an improved ABTS radical cation decolorization assay. Free Radic. Biol. Med. 1999, 26, 1231-1237. [CrossRef]

104. Huang, D.; Boxin, O.U.; Prior, R.L. The chemistry behind antioxidant capacity assays. J. Agric. Food Chem. 2005, 53, 1841-1856. [CrossRef]

105. Walker, R.B.; Everette, J.D. Comparative Reaction Rates of Various Antioxidants with ABTS Radical Cation. J. Agric. Food Chem. 2009, 57, 1156-1161. [CrossRef]

106. Chandra, S.; Khan, S.; Avula, B.; Lata, H.; Yang, M.H.; Elsohly, M.A.; Khan, I.A. Assessment of total phenolic and flavonoid content, antioxidant properties, and yield of aeroponically and conventionally grown leafy vegetables and fruit crops: A comparative study. Evid. Based. Complement. Altern. Med. 2014, 2014, 253875. [CrossRef] [PubMed]

107. Kim, J.S.; Ahn, J.; Lee, S.J.; Moon, B.K.; Ha, T.Y.; Kim, S. Phytochemicals and Antioxidant Activity of Fruits and Leaves of Paprika (Capsicum annuum L., var. Special) Cultivated in Korea. J. Food Sci. 2011, 76, C193-C198. [CrossRef]

108. Marín, A.; Ferreres, F.; Tomás-Barberán, F.A.; Gil, M.I. Characterization and quantitation of antioxidant constituents of sweet pepper (Capsicum annuum L.). J. Agric. Food Chem. 2004, 52, 3861-3869. [CrossRef] 
109. Howard, L.R.; Talcott, S.T.; Brenes, C.H.; Villalon, B. Changes in phytochemical and antioxidant activity of selected pepper cultivars (Capsicum species) as influenced by maturity. J. Agric. Food Chem. 2000, 48, 1713-1720. [CrossRef] [PubMed]

110. Morales-Soto, A.; Gómez-Caravaca, A.M.; García-Salas, P.; Segura-Carretero, A.; Fernández-Gutiérrez, A. High-performance liquid chromatography coupled to diode array and electrospray time-of-flight mass spectrometry detectors for a comprehensive characterization of phenolic and other polar compounds in three pepper (Capsicum annuum L.) samples. Food Res. Int. 2013, 51, 977-984. [CrossRef]

111. Medina-Juárez, L.Á.; Molina-Quijada, D.M.A.; Del Toro-Sánchez, C.L.; González-Aguilar, G.A.; Gámez-Meza, N. Antioxidant activity of peppers (Capsicum annum L.) extracts and characterization of their phenolic constituents. Interciencia 2012, 37, 588-593.

112. Chen, L.; Kang, Y.-H. Anti-inflammatory and antioxidant activities of red pepper (Capsicum annuum L.) stalk extracts: Comparison of pericarp and placenta extracts. J. Funct. Foods 2013, 5, 1724-1731. [CrossRef]

113. Mudrić, S.; Gašić, U.M.; Dramićanin, A.M.; Ćirić, I.Ž.; Milojković-Opsenica, D.M.; Popović-Đorđević, J.B.; Momirović, N.M.; Tešić, Ž.L. The polyphenolics and carbohydrates as indicators of botanical and geographical origin of Serbian autochthonous clones of red spice paprika. Food Chem. 2017, 217, 705-715. [CrossRef]

114. Kim, W.-R.; Kim, E.O.; Kang, K.; Oidovsambuu, S.; Jung, S.H.; Kim, B.S.; Nho, C.W.; Um, B.-H. Antioxidant activity of phenolics in leaves of three red pepper (Capsicum annuum) cultivars. J. Agric. Food Chem. 2014, 62, 850-859. [CrossRef]

115. Kashiwagi, T.; Horibata, Y.; Mekuria, D.B.; Tebayashi, S.-I.; Kim, C.-S. Ovipositional deterrent in the sweet pepper, Capsicum annuum, at the mature stage against Liriomyza trifolii (Burgess). Biosci. Biotechnol. Biochem. 2005, 69, 1831-1835. [CrossRef]

116. Del Rocio Moreno-Ramírez, Y.; Martínez-Ávila, G.C.G.; González-Hernández, V.A.; Castro-López, C.; Torres-Castillo, J.A. Free radical-scavenging capacities, phenolics and capsaicinoids in wild piquin chili (Capsicum annuum var. glabriusculum). Molecules 2018, 23, 2655. [CrossRef] [PubMed]

117. Ogunruku, O.O.; Oboh, G.; Passamonti, S.; Tramer, F.; Boligon, A.A. Capsicum annuum var. grossum (Bell Pepper) Inhibits $\beta$-Secretase Activity and $\beta$-Amyloid 1-40 Aggregation. J. Med. Food 2017, 20, 124-130. [CrossRef] [PubMed]

118. Mokhtar, M.; Soukup, J.; Donato, P.; Cacciola, F.; Dugo, P.; Riazi, A.; Jandera, P.; Mondello, L. Determination of the polyphenolic content of a Capsicum annuum L. extract by liquid chromatography coupled to photodiode array and mass spectrometry detection and evaluation of its biological activity. J. Sep. Sci. 2015, 38, 171-178. [CrossRef]

119. Park, S.; Jeong, W.Y.; Lee, J.H.; Kim, Y.H.; Jeong, S.W.; Kim, G.S.; Bae, D.W.; Lim, C.S.; Jin, J.S.; Lee, S.J.; et al. Determination of polyphenol levels variation in Capsicum annuum L. cv. Chelsea (yellow bell pepper) infected by anthracnose (Colletotrichum gloeosporioides) using liquid chromatography-tandem mass spectrometry. Food Chem. 2012, 130, 981-985. [CrossRef]

120. Jeong, W.Y.; Jin, J.S.; Cho, Y.A.; Lee, J.H.; Park, S.; Jeong, S.W.; Kim, Y.H.; Lim, C.S.; Abd El-Aty, A.M.; Kim, G.S.; et al. Determination of polyphenols in three Capsicum annuum L. (bell pepper) varieties using high-performance liquid chromatography tandem mass spectrometry: Their contribution to overall antioxidant and anticancer activity. J. Sep. Sci. 2011, 34, 2967-2974. [CrossRef]

121. Materska, M.; Piacente, S.; Stochmal, A.; Pizza, C.; Oleszekc, W.; Perucka, I. Isolation and structure elucidation of flavonoid and phenolic acid glycosides from pericarp of hot pepper fruit Capsicum annuum L. Phytochemistry 2003, 63, 893-898. [CrossRef]

122. Materska, M.; Perucka, I. Antioxidant activity of the main phenolic compounds isolated from hot pepper fruit (Capsicum annuum L.). J. Agric. Food Chem. 2005, 53, 1750-1756. [CrossRef]

123. Lee, Y.; Howard, L.R.; Villarón, B. Flavonoids and antioxidant activity of fresh pepper (Capsicum annuum) cultivars. J. Food Sci. 1995, 60, 473-476. [CrossRef]

124. Jang, Y.K.; Jung, E.S.; Lee, H.A.; Choi, D.; Lee, C.H. Metabolomic characterization of hot pepper (Capsicum annuum "cM334") during fruit development. J. Agric. Food Chem. 2015, 63, 9452-9460. [CrossRef]

125. Sadilova, E.; Stintzing, F.C.; Carle, R. Anthocyanins, color and antioxidant properties of eggplant (Solanum melongena L.) and violet pepper (Capsicum annuum L.) peel extracts. Z. Naturforsch. C J. Biosci. 2006, 61, 527-535. [CrossRef] 
126. Lightbourn, G.J.; Griesbach, R.J.; Novotny, J.A.; Clevidence, B.A.; Rao, D.D.; Stommel, J.R. Effects of anthocyanin and carotenoid combinations on foliage and immature fruit color of Capsicum annuum L. J. Hered. 2008, 99, 105-111. [CrossRef] [PubMed]

127. Tundis, R.; Loizzo, M.R.; Menichini, F.; Bonesi, M.; Conforti, F.; Statti, G.; De Luca, D.; de Cindio, B.; Menichini, F. Comparative study on the chemical composition, antioxidant properties and hypoglycaemic activities of two Capsicum annuum L. cultivars (Acuminatum small and Cerasiferum). Plant Foods Hum. Nutr. 2011, 66, 261-269. [CrossRef]

128. Sun, T.; Xu, Z.; Wu, C.T.; Janes, M.; Prinyawiwatkul, W.; No, H.K. Antioxidant activities of different colored sweet bell peppers (Capsicum annuum L.). J. Food Sci. 2007, 72, S98-S102. [CrossRef]

129. Ichiyanagi, T.; Kashiwada, Y.; Shida, Y.; Ikeshiro, Y.; Kaneyuki, T.; Konishi, T. Nasunin from eggplant consists of cis-trans isomers of delphinidin 3-[4-(p-coumaroyl)-L-rhamnosyl $(1 \rightarrow 6)$ glucopyranoside]-5-glucopyranoside. J. Agric. Food Chem. 2005, 53, 9472-9477. [CrossRef] [PubMed]

130. Poiroux-Gonord, F.; Bidel, L.P.R.; Fanciullino, A.L.; Gautier, H.; Lauri-Lopez, F.; Urban, L. Health benefits of vitamins and secondary metabolites of fruits and vegetables and prospects to increase their concentrations by agronomic approaches. J. Agric. Food Chem. 2010, 58, 12065-12082. [CrossRef] [PubMed]

131. Perry, L.; Dickau, R.; Zarrillo, S.; Holst, I.; Pearsall, D.M.; Piperno, D.R.; Berman, M.J.; Cooke, R.G.; Rademaker, K.; Ranere, A.J.; et al. Starch fossils and the domestication and dispersal of chili peppers (Capsicum spp. L.) in the Americas. Science 2007, 315, 986-988. [CrossRef]

132. Paran, I.; Van Der Knaap, E. Genetic and molecular regulation of fruit and plant domestication traits in tomato and pepper. J. Exp. Bot. 2007, 58, 3841-3852. [CrossRef]

133. Rousseaux, M.C.; Jones, C.M.; Adams, D.; Chetelat, R.; Bennett, A.; Powell, A. QTL analysis of fruit antioxidants in tomato using Lycopersicon pennellii introgression lines. Theor. Appl. Genet. 2005, 111, 1396-1408. [CrossRef]

134. Di Matteo, A.; Ruggieri, V.; Sacco, A.; Rigano, M.M.; Carriero, F.; Bolger, A.; Fernie, A.R.; Frusciante, L.; Barone, A. Identification of candidate genes for phenolics accumulation in tomato fruit. Plant Sci. 2013, 205-206, 87-96. [CrossRef]

135. McCown, B.; Zeldin, E. "HyRed", an early, high fruit color cranberry hybrid. HortScience 2003, 23, 304-305. [CrossRef]

136. Khanizadeh, S.; Ehsani-Moghaddam, B.; Levasseur, A. Antioxidant capacity in June-bearing and day-neutral strawberry. Can. J. Plant Sci. 2006, 86, 1387-1390. [CrossRef]

137. Cevallos-Casals, B.A.; Byrne, D.; Okie, W.R.; Cisneros-Zevallos, L. Selecting new peach and plum genotypes rich in phenolic compounds and enhanced functional properties. Food Chem. 2006, 96, 273-280. [CrossRef]

138. Verhoeyen, M.E. Increasing antioxidant levels in tomatoes through modification of the flavonoid biosynthetic pathway. J. Exp. Bot. 2002, 53, 2099-2106. [CrossRef] [PubMed]

139. Giovinazzo, G.; D'Amico, L.; Paradiso, A.; Bollini, R.; Sparvoli, F.; DeGara, L. Antioxidant metabolite profiles in tomato fruit constitutively expressing the grapevine stilbene synthase gene. Plant Biotechnol. J. 2005, 3, 57-69. [CrossRef]

140. Schijlen, E.; Ric De Vos, C.H.; Jonker, H.; Van Den Broeck, H.; Molthoff, J.; Van Tunen, A.; Martens, S.; Bovy, A. Pathway engineering for healthy phytochemicals leading to the production of novel flavonoids in tomato fruit. Plant Biotechnol. J. 2006, 4, 433-444. [CrossRef] [PubMed]

141. Van Der Rest, B.; Danoun, S.; Boudet, A.M.; Rochange, S.F. Down-regulation of cinnamoyl-CoA reductase in tomato (Solanum lycopersicum L.) induces dramatic changes in soluble phenolic pools. J. Exp. Bot. 2006, 57, 1399-1411. [CrossRef] [PubMed]

142. Bovy, A. High-flavonol tomatoes resulting from the heterologous expression of the maize transcription factor genes LC and C1. Plant Cell Online 2002, 14, 2509-2526. [CrossRef]

143. Butelli, E.; Titta, L.; Giorgio, M.; Mock, H.P.; Matros, A.; Peterek, S.; Schijlen, E.G.W.M.; Hall, R.D.; Bovy, A.G.; Luo, J.; et al. Enrichment of tomato fruit with health-promoting anthocyanins by expression of select transcription factors. Nat. Biotechnol. 2008, 26, 1301-1308. [CrossRef] [PubMed]

144. Løvdal, T.; Olsen, K.M.; Slimestad, R.; Verheul, M.; Lillo, C. Synergetic effects of nitrogen depletion, temperature, and light on the content of phenolic compounds and gene expression in leaves of tomato. Phytochemistry 2010, 71, 605-613. [CrossRef] [PubMed] 
145. Selmar, D.; Kleinwächter, M. Stress enhances the synthesis of secondary plant products: The impact of stress-related over-reduction on the accumulation of natural products. Plant Cell Physiol. 2013, 54, 817-826. [CrossRef] [PubMed]

146. Ramakrishna, A.; Ravishankar, G.A. Influence of abiotic stress signals on secondary metabolites in plants. Plant Signal. Behav. 2011, 6, 1720-1731. [CrossRef]

147. Yang, L.; Wen, K.S.; Ruan, X.; Zhao, Y.X.; Wei, F.; Wang, Q. Response of plant secondary metabolites to environmental factors. Molecules 2018, 23, 762. [CrossRef] [PubMed]

148. Selmar, D.; Kleinwächter, M. Influencing the product quality by deliberately applying drought stress during the cultivation of medicinal plants. Ind. Crops Prod. 2013, 42, 558-566. [CrossRef]

149. Bénard, C.; Gautier, H.; Bourgaud, F.; Grasselly, D.; Navez, B.; Caris-Veyrat, C.; Weiss, M.; Génard, M. Effects of low nitrogen supply on tomato (Solanum lycopersicum) fruit yield and quality with special emphasis on sugars, acids, ascorbate, carotenoids, and phenolic compounds. J. Agric. Food Chem. 2009, 57, 4112-4123. [CrossRef] [PubMed]

150. Schonhof, I.; Kläring, H.P.; Krumbein, A.; Claußen, W.; Schreiner, M. Effect of temperature increase under low radiation conditions on phytochemicals and ascorbic acid in greenhouse grown broccoli. Agric. Ecosyst. Environ. 2007, 119, 103-111. [CrossRef]

151. Wang, S.Y.; Zheng, W. Effect of plant growth temperature on antioxidant capacity in strawberry. J. Agric. Food Chem. 2001, 49, 4977-4982. [CrossRef] [PubMed]

152. Ju, Z.; Duan, Y.; Ju, Z. Effects of covering the orchard floor with reflecting films on pigment accumulation and fruit coloration in "Fuji" apples. Sci. Hortic. 1999, 82, 47-56. [CrossRef]

153. Wilkens, R.T.; Spoerke, J.M.; Stamp, N.E. Differential responses of growth and two soluble phenolics of tomato to resource availability. Ecology 1996, 77, 247-258. [CrossRef]

154. Gautier, H.; Diakou-Verdin, V.; Bénard, C.; Reich, M.; Buret, M.; Bourgaud, F.; Poëssel, J.L.; Caris-Veyrat, C.; Génard, M. How does tomato quality (sugar, acid, and nutritional quality) vary with ripening stage, temperature, and irradiance? J. Agric. Food Chem. 2008, 56, 1241-1250. [CrossRef]

155. Torres, C.A.; Andrews, P.K.; Davies, N.M. Physiological and biochemical responses of fruit exocarp of tomato (Lycopersicon esculentum Mill.) mutants to natural photo-oxidative conditions. J. Exp. Bot. 2006, 57, 1933-1947. [CrossRef] [PubMed]

156. Navarro, J.M.; Flores, P.; Garrido, C.; Martinez, V. Changes in the contents of antioxidant compounds in pepper fruits at different ripening stages, as affected by salinity. Food Chem. 2006, 96, 66-73. [CrossRef]

157. Keutgen, A.J.; Pawelzik, E. Modifications of strawberry fruit antioxidant pools and fruit quality under $\mathrm{NaCl}$ stress. J. Agric. Food Chem. 2007, 55, 4066-4072. [CrossRef]

158. De Pascale, S.; Martino, A.; Raimondi, G.; Maggio, A. Comparative analysis of water and salt stress-induced modifications of quality parameters in cherry tomatoes. J. Hortic. Sci. Biotechnol. 2007, 82, 283-289. [CrossRef]

159. Anttonen, M.J.; Hoppula, K.I.; Nestby, R.; Verheul, M.J.; Karjalainen, R.O. Influence of fertilization, mulch color, early forcing, fruit order, planting date, shading, growing environment, and genotype on the contents of selected phenolics in strawberry (Fragaria x ananassa Duch.) fruits. J. Agric. Food Chem. 2006, 54, 2614-2620. [CrossRef]

160. Lekala, C.S.; Madani, K.S.H.; Phan, A.D.T.; Maboko, M.M.; Fotouo, H.; Soundy, P.; Sultanbawa, Y.; Sivakumar, D. Cultivar-specific responses in red sweet peppers grown under shade nets and controlled-temperature plastic tunnel environment on antioxidant constituents at harvest. Food Chem. 2019, 175, 85-94. [CrossRef]

161. Ribes-Moya, A.M.; Raigón, M.D.; Moreno-Peris, E.; Fita, A.; Rodríguez-Burruezo, A. Response to organic cultivation of heirloom Capsicum peppers: Variation in the level of bioactive compounds and effect of ripening. PLoS ONE 2018, 13. [CrossRef]

162. Narayani, M.; Srivastava, S. Elicitation: A stimulation of stress in in vitro plant cell/tissue cultures for enhancement of secondary metabolite production. Phytochem. Rev. 2017, 16, 1227-1252. [CrossRef]

163. Bourgaud, F.; Gravot, A.; Milesi, S.; Gontier, E. Production of plant secondary metabolites: A historical perspective. Plant Sci. 2001, 161, 839-851. [CrossRef]

164. Ramirez-Estrada, K.; Vidal-Limon, H.; Hidalgo, D.; Moyano, E.; Golenioswki, M.; Cusidó, R.M.; Palazon, J. Elicitation, an effective strategy for the biotechnological production of bioactive high-added value compounds in plant cell factories. Molecules 2016, 21, 182. [CrossRef] 
165. Wasternack, C.; Strnad, M. Jasmonates are signals in the biosynthesis of secondary metabolites-Pathways, transcription factors and applied aspects-A brief review. New Biotechnol. 2019, 48, 1-11. [CrossRef]

166. Heredia, J.B.; Cisneros-Zevallos, L. The effect of exogenous ethylene and methyl jasmonate on pal activity, phenolic profiles and antioxidant capacity of carrots (Daucus carota) under different wounding intensities. Postharvest Biol. Technol. 2009, 51, 242-249. [CrossRef]

167. Hendrawati, O.; Yao, Q.; Kim, H.K.; Linthorst, H.J.M.; Erkelens, C.; Lefeber, A.W.M.; Choi, Y.H.; Verpoorte, R. Metabolic differentiation of Arabidopsis treated with methyl jasmonate using nuclear magnetic resonance spectroscopy. Plant Sci. 2006, 170, 1118-1124. [CrossRef]

168. Mejía-Teniente, L.; de Dalia Duran-Flores, F.; Chapa-Oliver, A.M.; Torres-Pacheco, I.; Cruz-Hernández, A.; González-Chavira, M.M.; Ocampo-Velázquez, R.V.; Guevara-González, R.G. Oxidative and molecular responses in Capsicum annuum L. after hydrogen peroxide, salicylic acid and chitosan foliar applications. Int. J. Mol. Sci. 2013, 14, 10178-10196. [CrossRef]

169. Groher, T.; Schmittgen, S.; Noga, G.; Hunsche, M. Limitation of mineral supply as tool for the induction of secondary metabolites accumulation in tomato leaves. Plant Physiol. Biochem. 2018, 130, 105-111. [CrossRef] [PubMed]

170. Padilla, F.M.; Peña-Fleitas, M.T.; Fernández, M.D.; del Moral, F.; Thompson, R.B.; Gallardo, M. Responses of soil properties, crop yield and root growth to improved irrigation and $\mathrm{N}$ fertilization, soil tillage and compost addition in a pepper crop. Sci. Hortic. 2017, 225, 422-430. [CrossRef]

171. Usadel, B.; Wormit, A. InducTomE. Available online: http://www.biosc.de/inductome (accessed on 29 March 2019).

(C) 2019 by the authors. Licensee MDPI, Basel, Switzerland. This article is an open access article distributed under the terms and conditions of the Creative Commons Attribution (CC BY) license (http://creativecommons.org/licenses/by/4.0/). 